\title{
Towards observation-based gridded runoff estimates for Europe
}

\author{
L. Gudmundsson and S. I. Seneviratne \\ Institute for Atmospheric and Climate Science, ETH Zurich, Universitaetstrasse 16, 8092 Zurich, Switzerland \\ Correspondence to: L. Gudmundsson (lukas.gudmundsson@env.ethz.ch) and S. I. Seneviratne (sonia.seneviratne@ethz.ch) \\ Received: 13 October 2014 - Published in Hydrol. Earth Syst. Sci. Discuss.: 18 November 2014 \\ Revised: 5 May 2015 - Accepted: 20 May 2015 - Published: 22 June 2015
}

\begin{abstract}
Terrestrial water variables are the key to understanding ecosystem processes, feed back on weather and climate, and are a prerequisite for human activities. To provide context for local investigations and to better understand phenomena that only emerge at large spatial scales, reliable information on continental-scale freshwater dynamics is necessary. To date streamflow is among the best-observed variables of terrestrial water systems. However, observation networks have a limited station density and often incomplete temporal coverage, limiting investigations to locations and times with observations. This paper presents a methodology to estimate continental-scale runoff on a $0.5^{\circ}$ spatial grid with monthly resolution. The methodology is based on statistical upscaling of observed streamflow from small catchments in Europe and exploits readily available gridded atmospheric forcing data combined with the capability of machine learning techniques. The resulting runoff estimates are validated against (1) runoff from small catchments that were not used for model training, (2) river discharge from nine continental-scale river basins and (3) independent estimates of long-term mean evapotranspiration at the pan-European scale. In addition it is shown that the produced gridded runoff compares on average better to observations than a multi-model ensemble of comprehensive land surface models (LSMs), making it an ideal candidate for model evaluation and model development. In particular, the presented machine learning approach may help determining which factors are most relevant for an efficient modelling of runoff at regional scales. Finally, the resulting data product is used to derive a comprehensive runoff climatology for Europe and its potential for drought monitoring is illustrated.
\end{abstract}

\section{Introduction}

Terrestrial water storages and fluxes are key variables in the Earth system, as they are a primary control for many ecosystem processes (e.g. Ciais et al., 2005; Granier et al., 2007; Reichstein et al., 2013; Guan et al., 2015), influence weather and climate through land-atmosphere interactions (e.g. Koster et al., 2004; Seneviratne et al., 2010) and are the basis for many human activities (e.g Döll et al., 2009; Vörösmarty et al., 2010; Orlowsky et al., 2014). Consequently, information of the historical space and time evolution of variables such as evapotranspiration, soil moisture, groundwater and runoff are of great interest. However, most of these variables are only observed at few locations in space and often with irregular temporal coverage, limiting analysis to the well-monitored regions. Consequently, data products providing reliable estimates of the historical space-time evolution of these variables for large, continental-scale regions are of vital importance. Such data products will not only allow investigating terrestrial water dynamics at locations without observations but more importantly also allow for the study of processes and phenomena that emerge on large, continental, scales. Such studies include but are not limited to

1. the analysis of fresh water climatologies (e.g. Dettinger and Diaz, 2000; Fekete et al., 2002; Reager and Famiglietti, 2013);

2. the assessment of large-scale droughts (e.g. Sheffield et al., 2012; Tallaksen and Stahl, 2014; Thomas et al., 2014; Gudmundsson et al., 2014; Gudmundsson and Seneviratne, 2015);

3. the validation of land surface models (LSMs) and hydrological models used at large scales (e.g. Dirmeyer et al., 2006, Haddeland et al., 2011; Gudmundsson et al., 2012a, b; Schewe et al., 2014); 
4. investigating the link between climate variability and terrestrial water dynamics, including feedbacks (e.g. Tootle and Piechota, 2006; Jung et al., 2010; Gudmundsson et al., 2011b; Mueller and Seneviratne, 2012; de Linage et al., 2014; Miralles et al., 2014);

5. analysing the effect of climate change on freshwater resources (e.g. Krakauer and Fung, 2008; Stahl et al., 2012; Famiglietti and Rodell, 2013; Greve et al., 2014).

To date, two main approaches for continental- to globalscale estimation of terrestrial water dynamics are in use. The first approach is based on LSMs that are driven by historical atmospheric forcing (e.g. Fekete et al., 2002; Rodell et al., 2004; Dirmeyer et al., 2006; Fekete et al., 2011; Balsamo et al., 2013). While LSM-based estimates are attractive because they provide comprehensive information on a large number of relevant variables, the resulting data are still highly model dependent and large uncertainties remain (e.g Haddeland et al., 2012; Gudmundsson et al., 2012a, b; Mueller et al., 2011b, 2013; Prudhomme et al., 2014). In recent years, the rapid evolution of satellite remote sensing has allowed providing estimates of selected variables including soil moisture (e.g. Wagner et al., 2007; de Jeu et al., 2008; Seneviratne et al., 2010) and total terrestrial water storage (e.g Houborg et al., 2012; Landerer and Swenson, 2012; Rodell and Famiglietti, 1999; Famiglietti and Rodell, 2013). However, satellite observations only cover a relatively short time window and issues such as inhomogeneities due to changes in instrumentation and uncertainties in retrieval algorithms are still limiting their application (Loew et al., 2013; Hirschi et al., 2014).

A common feature of the abovementioned approaches is that they only exploit in situ observations of terrestrial water variables to a very limited degree. Historically, catchment runoff is likely the best-monitored variable of terrestrial water systems, which has been observed for centuries to decades at thousands of locations covering the entire globe (Slack and Landwehr, 1992; Hannah et al., 2011; Fekete et al., 2012). Other variables such as evapotranspiration or soil moisture have received less attention and consequently respective ground observations are available at fewer locations and often cover much shorter time periods (Baldocchi, 2008; Seneviratne et al., 2010; Dorigo et al., 2013). Nevertheless Jung et al. (2009, 2010, 2011) successfully derive global estimates of evapotranspiration, sensible heat flux and carbon exchange on the basis of in situ observations of the FLUXNET observatories (Baldocchi, 2008) using machine learning techniques.

Technically speaking, Jung et al. (2009, 2010, 2011) did build a nonlinear regression model that predicts landatmosphere fluxes as a function of gridded atmospheric variables (e.g. precipitation) and remotely sensed information on vegetation activity. As the nonlinearity of the underlying processes prevents the identification of parametric regression models, the application of machine learning is neces- sary. This is also illustrated by Beck et al. (2013), who used neural networks to estimate global maps of several streamflow characteristics, including the baseflow index.

The presented study proposes a framework for estimating the historical space-time evolution of runoff in Europe on the basis of observations from small catchments. Following Jung et al. $(2009,2010,2011)$ we combine the advantage of in situ observations and the availability of gridded atmospheric observations with machine learning techniques to derive estimates of monthly runoff in Europe on a regular spatial grid. The accuracy of the estimated runoff fields is assessed with respect to data that were not used for model identification and compared to an ensemble of comprehensive land surface models. Finally, example applications of the resulting data product are provided and implications from the empirical modelling exercise are discussed in the context of physical model development.

\section{Data}

\subsection{Modelling data}

\subsubsection{Atmospheric forcing}

Estimates of atmospheric near-surface variables were taken from the WATCH forcing data (WFD; Weedon et al., 2011), which are available on a regular $0.5^{\circ} \times 0.5^{\circ}$ grid. The WFD were developed in the context of the WATCH (Water and Global Change) project (http://www.eu-watch.org/, last access: 24 June 2014). The analysis is based on the full WFD, covering the following set of variables: rainfall, snowfall, air temperature, incoming long- and short-wave radiations, humidity, surface pressure and wind speed. The WFD are available at subdaily resolution and were aggregated to monthly mean values.

\subsubsection{Runoff observations}

The investigation is based on 426 streamflow series from small undisturbed catchments, covering the 1963-2000 time period (Fig. 1). The data are a subset (see Stahl et al., 2010, for details) of the European Water Archive (EWA). The EWA is collected by the European Flow Regimes from International Experimental and Network Data (Euro-FRIEND) project (http://ne-friend.bafg.de/servlet/is/7413/, last access: 24 June 2014) and held by the Global Runoff Data Centre (GRDC; http://grdc.bafg.de, last access: 24 June 2014).

As the majority of the considered catchments is much smaller than the $0.5^{\circ}$ grid cells of the atmospheric forcing data (Fig. 1), the time series of the individual catchments were assigned to the corresponding grid cells. Following previous studies (Arnell, 1995; Gudmundsson et al., 2011 b 2012b, a), streamflow observations from the individual catchments were first converted into runoff rates per unit area and the coordinates of the gauging stations were 


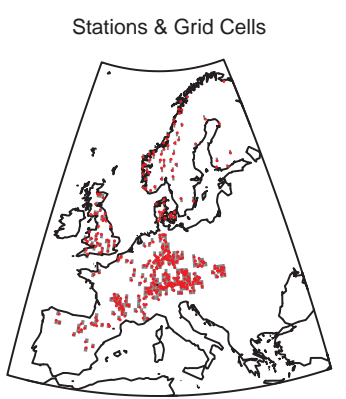

- Grid Cell • Station

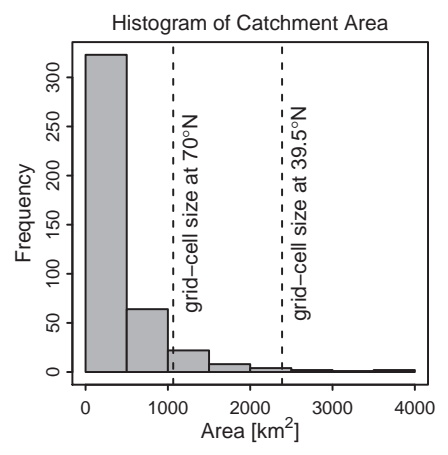

Figure 1. Runoff observations. Left: locations of the gauging stations of the considered catchments, as well as the grid cells with observations. Right: histogram of catchment areas. The vertical lines indicate the grid-cell size of the southern and northernmost grid cells.

assigned to the $0.5^{\circ}$ grid cells defined by the atmospheric forcing data. If more than one gauging station occurred in one catchment, the catchment area weighted average runoff rate was used. This procedure results in 298 grid cells with observed daily runoff rates, which were subsequently aggregated to mean monthly values (Fig. 1).

In the following the monthly mean grid-cell-averaged runoff rates are referred to as "observed runoff". Although streamflow, which is used to compute these estimate, is different from runoff we argue that the differences between the two quantities become small at the considered space scales and timescales. The main difference between streamflow and runoff is that the former has been routed trough a channel network. However, the associated processes operate on timescales that are much smaller than the resolution of the presented analysis. For example, hydrograph wave speeds are approximately $0.5 \mathrm{~m} \mathrm{~s}^{-1}=1.8 \mathrm{~km} \mathrm{~h}^{-1}=43.2 \mathrm{~km} \mathrm{~d}^{-1}$ (e.g. Wong and Laurenson, 1983), implying that at least daily resolution would be required to resolve these processes for $0.5^{\circ}$ grid cells. At monthly timescales, however, total catchment runoff can be assumed to equal the sum of streamflow if water losses through e.g. channel evaporation are negligible.

As the present study operates on monthly resolution and on a $0.5^{\circ}$ grid $(\approx 50 \mathrm{~km})$, it is consequently unlikely that effects of channel routing will impair the results.

\subsubsection{Land parameters}

Median grid-cell slope was derived from the HYDRO1k data set which is available from the US Geological Survey (Fig. 2). Information on soil texture for each grid cell (median fraction of clay, silt, sand, gravel) were taken from the Harmonized World Soil Database (version 1.2) (FAO et al., 2012) (Fig. 3).
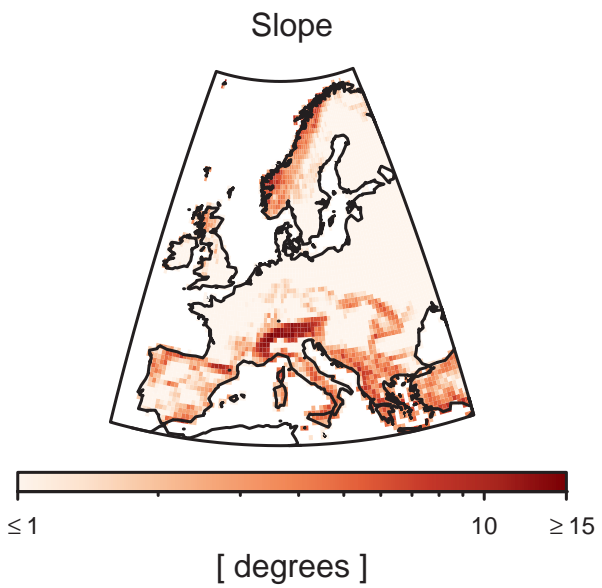

Figure 2. Median grid-cell slope.
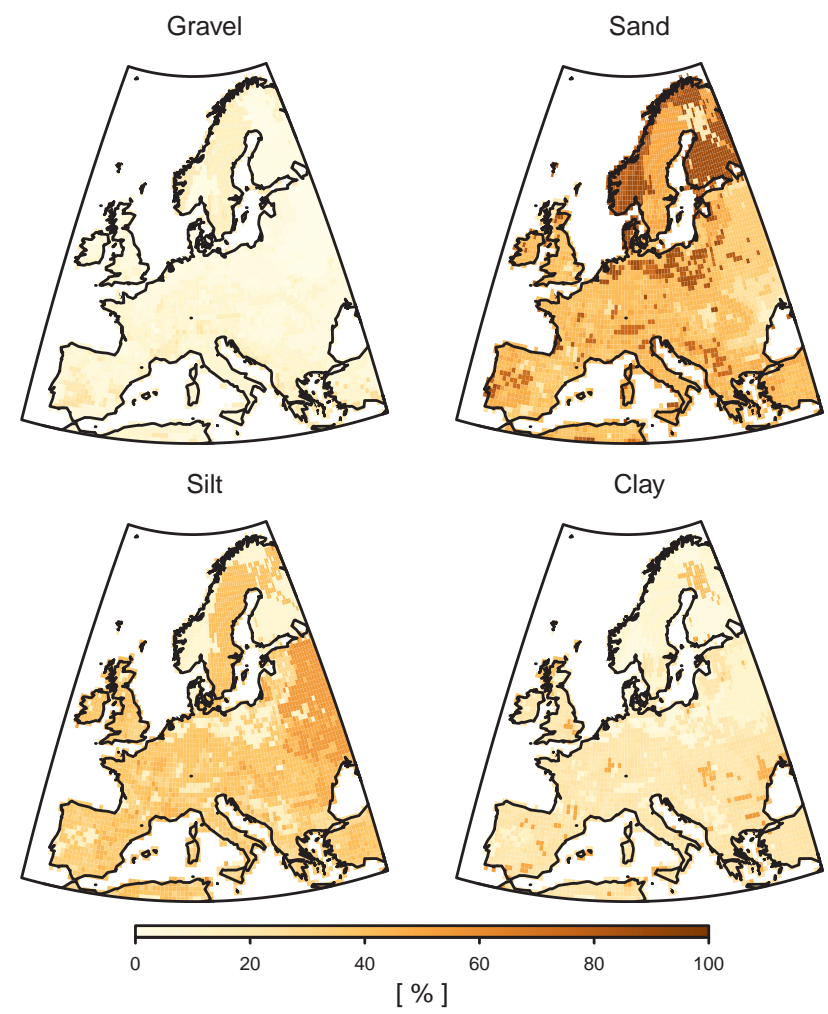

Figure 3. Soil texture: median fraction of gravel, sand, silt and clay.

\subsection{Validation data}

\subsubsection{Continental-scale river discharge}

Observed monthly discharge from nine continental-scale river basins (Ebro, Elbe, Garonne, Loire, Po, Rhine, Rhone, Seine, Weser) and corresponding catchment shapes where taken from a previously assembled collection (see Hirschi et al., 2006 and Mueller et al., 2011a for details). 


\subsubsection{Long-Term mean evapotranspiration}

A comprehensive estimate of the long-term mean (19891995) land evapotranspiration was taken from the LandFluxEVAL synthesis product (Mueller et al., 2013), which combines information from 40 distinct evapotranspiration estimates on a $2^{\circ}$ grid.

\subsection{Comparison Data}

The results of the statistical modelling exercise were also compared to runoff simulations from nine state-of-the-art LSMs, developed by the WATCH project. Details on the simulation setup, key features of the participating models, and further model validation can be found in the literature (Haddeland et al., 2011; Gudmundsson et al., 2012b, a). All participating models were forced using the WFD which guarantees a fair comparison with the statistical runoff estimates introduced in this study. The LSM runoff simulations were augmented by the multi-model mean (MMM).

\section{Methods}

\subsection{Statistical model setup}

The aim of this study is to estimate monthly runoff, $Q_{x, t}$, at different land units $x$ and time steps $t$. To achieve this, $Q_{x, t}$ is related to a set of explanatory variables that are available at all locations within the spatial domain through a machine learning model $h$, which is described in detail in Sect. 3.2.

We derive three models of various degrees of complexity. The simplest case assessed in this study is solely based on gridded precipitation, $P_{x, t}$, and temperature, $T_{x, t}$, such that

$Q_{x, t}=h\left(\tau_{n}\left(P_{x, t}\right), \tau_{n}\left(T_{x, t}\right)\right)$,

where the time lag operator $\tau_{n}$ is defined as $\tau_{n}\left(X_{x, t}\right)=$ $\left[X_{x, t}, X_{x, t-1}, \ldots, X_{x, t-n}\right]$ and gives access to atmospheric conditions over the past $n$ time steps (months). This time lag operator allows us to approximate storage effects that are relevant for runoff generation. In the presented analysis, input from the previous year is considered $(n=11)$, which enables the model to take limited storage processes related e.g. to groundwater and snow into account. Note also that the model $h$ is only identified once and is applicable at all locations in space. This implies that all information on spatial variability only comes from the atmospheric input data. As the WFD provides separate information on rain and snowfall, precipitation is here defined as the sum of both components. This simple setup is motivated by the tradition that runoff modelling at catchment scales relies in many cases only on precipitation and temperature forcing.

The second model setup is defined as

$Q_{x, t}=h\left(\tau_{n}\left(I_{x, t}^{1}\right), \tau_{n}\left(I_{x, t}^{2}\right), \ldots, \tau_{n}\left(I_{x, t}^{p}\right)\right)$, where $I_{x, t}^{1}, \ldots, I_{x, t}^{p}$ are all atmospheric forcing variables available within the WFD (see Sect. 2.1.1). The rationale underlying this approach is that processes such as evapotranspiration and snow dynamics do not only depend on precipitation and temperature but also on many other forcing variables including humidity, wind speed and different radiation components.

Finally, the most complex model setup is specified as

$Q_{x, t}=h\left(\tau_{n}\left(I_{x, t}^{1}\right), \tau_{n}\left(I_{x, t}^{2}\right), \ldots, \tau_{n}\left(I_{x, t}^{p}\right), \Pi_{x}\right)$,

where $\Pi_{x}$ is a vector, containing information on slope and soil texture (see Sect. 2.1.1). The idea underlying this last setup is to increase the realism of the statistical model, as terrestrial water dynamics is not only dependent on atmospheric forcing but also on local variations in land properties which influence runoff generation.

\subsection{Model identification}

The practical challenge in the application of Eqs. (1)-(3) is the identification of the model $h$. For this we follow Jung et al. $(2009,2010,2011)$ and exploit the capability of modern machine learning techniques. In contrast to Jung et al. (2009, 2010, 2011), who used model tree ensembles, we employ here a closely related method called random forests (RF) (Breiman, 2001). The use of RF is a pragmatic choice, as this technique is well established, requires only few user specifications (see e.g. Hastie et al., 2009) and is implemented in standard software environments (e.g. Liaw and Wiener, 2002). Note, however, that other machine learning tools such as boosting techniques, neural networks or support vector machines are likely to have similar performance (e.g. Bishop, 2006; Hastie et al., 2009).

Technically, RF are based on large ensembles of a modified version of classification and regression trees, each grown on a bootstrap sample of the data. Despite its considerable complexity, the RF algorithm (Breiman, 2001; Liaw and Wiener, 2002; Hastie et al., 2009) can be summarised in a simplified manner as follows.

1. Draw $B$ bootstrap samples from the data.

2. For each bootstrap sample, grow a random forest tree by recursively repeating the following steps.

(a) select $m$ of the available predictor variables at random.

(b) among the $m$-selected variables, find the one with the split point that best partitions the data.

(c) Split the data into two nodes and repeat the two previous steps on each node until the terminal node has reached the minimum node size $n$.

3. The RF prediction for new data is the average of the predictions of the $B$ individual trees. 
The free parameters of RFs need to be specified by the user. We opted for $B=1000, n=10$, and $m=p / 3$, where $p$ is the number of predictor variables, following recommendations in the literature (Hastie et al., 2009). In general, we found the results to be little sensitive to the parameter choice as long as the number of grown trees $(B)$ was large enough.

\subsection{Model selection and validation}

\subsubsection{Cross validation}

An important issue in statistical modelling is the fact that using the same data for model identification and model evaluation can result in too optimistic estimates of model performance. Therefore, the results of machine learning tools are commonly assessed using $K$-fold cross validation (e.g. Bishop, 2006; Hastie et al., 2009). Cross validation guarantees that the data used for model validation are independent from the data used for model identification. For cross validation, the data are first randomly split into $K$ subsamples. Subsequently one of the subsamples is removed and the model is trained on the remaining $K-1$ subsamples. Finally, the resulting model is used to predict the data that have been left out. These steps are repeated $K$ times until each subsample has been left out once. The procedure consequently results in predictions of the data that are independent of the data used for model identification.

To enhance the interpretability of cross validation in the context of this study we focus on the following two modifications of the usual cross validation procedure: in a first experiment, the focus is on the model's ability to estimate runoff at spatial locations $(x)$ that were not used for model identification. For this, the grid cells with observations are randomly split into $K=10$ subsamples, which were successively left out for model training. This procedure guarantees that at each location with observations, model estimates are available that are independent of the data used for model identification. In the following we refer to this procedure as "cross validation in space". Note that this validation strategy makes the analysis compatible with the Prediction of Ungauged Basins (PUB) initiative (Sivapalan et al., 2003; Blöschl et al., 2013; Hrachowitz et al., 2013; Parajka et al., 2013) of the International Association of Hydrological Sciences (IAHS). In a second experiment the focus is on the model's ability to estimate runoff dynamics at time steps $(t)$ that were not used for model identification. For this, the data were split into $K=10$ continuous time blocks, which were successively left out once for model training. This procedure is referred to as "cross validation in time" and provides estimates of runoff at time steps that were not used for model identification.

\subsubsection{Model selection}

Model selection is based on the total root mean square error, integrating model accuracy over space and time:

$\mathrm{RMSE}=\sqrt{\sum_{x, t}\left(m_{x, t}-o_{x, t}\right)^{2}}$,

where $m_{x, t}$ and $o_{x, t}$ refer to the modelled and observed values respectively. RMSE for each of the candidate models (Sect. 3.1) is estimated based on the two cross validation experiments. Uncertainty of the RMSE is quantified using $95 \%$ bootstrap confidence intervals with 2000 replications.

\subsubsection{Model validation}

Model performance is assessed for individual grid cells, where $o_{t}$ refers to the observed and $m_{t}$ to the modelled runoff series. Model performance is quantified using six different performance metrics, each focusing on different aspects of runoff dynamics.

1. The seasonal cycle skill score (Wilks, 2011) is defined as

$S_{\text {seas }}=1-\frac{\sum_{t}\left(m_{t}-o_{t}\right)^{2}}{\sum_{t}\left(m_{t}-\operatorname{seas}\left(o_{t}\right)\right)^{2}}$,

where seas $\left(o_{t}\right)$ refers to the long-term mean runoff for each month. $S_{\text {seas }} \in(-\infty, 1]$ and positive values indicate that the model is on average closer to the observations than the mean annual cycle.

2. The model efficiency (Nash and Sutcliffe, 1970; Wilks, 2011) is defined as

$\mathrm{MEf}=1-\frac{\sum_{t}\left(m_{t}-o_{t}\right)^{2}}{\sum_{t}\left(m_{t}-\operatorname{mean}\left(o_{t}\right)\right)^{2}}$,

where mean $\left(o_{t}\right)$ refers to the long-term mean of the observation. $S_{\mathrm{MEf}} \epsilon(-\infty, 1]$ and positive values indicate that the model is on average closer to the observations than the mean of the observations.

3. The relative model bias is defined as

$\mathrm{BIAS}=\frac{\operatorname{mean}\left(m_{t}-o_{t}\right)}{\operatorname{mean}\left(o_{t}\right)}$,

i.e. the mean difference between observed and modelled values scaled by the mean of the observations. The optimal value is zero and positive (negative) values indicate overestimation (underestimation) of the mean runoff.

4. The coefficient of determination (squared correlation coefficient), $R^{2}$, measures the agreement between the temporal evolution of the modelled and observed series. 
5. The coefficient of determination between the observed and the modelled mean annual cycle, Climatology- $R^{2}$, is sensitive to differences in the phasing of the mean annual cycle.

6. The coefficient of determination between the monthly anomalies (i.e. monthly time series with the long-term mean of each month removed), Anomaly- $R^{2}$, indicates the agreement between observed and modelled values after removing the mean seasonal cycle.

\section{Results}

\subsection{Model selection}

Figure 4 shows the RMSE of the RFM (random forest model) for all three model setups and both cross validation experiments. For the cross validation in space, the model that only depends on precipitation and temperature (Eq. 1) has the largest error and the two other models (Eqs. 2,3) have almost equal performance. The situation differs for the cross validation in time. Here the model with full atmospheric forcing (Eq. 2) significantly outperforms the other two models. As the model with full atmospheric forcing shows the best performance in both cross validation experiments it was selected and is considered for further analysis. In the following RFM refers to this selected model, unless specified differently.

\subsection{Model validation}

\subsubsection{Grid-cell-scale validation}

Figure 5 shows the RMSE of the RFM, derived from the cross validation in space experiment at each grid cell with observations as well as time series of observed and modelled runoff at the grid cells with the smallest, the median and the largest error. The grid-cell error shows some spatial patterns, with a tendency to increase in mountainous regions where observed runoff rates are highest. The selected time series allow for a qualitative assessment of the strengths and shortcomings of the RFM, indicating a good agreement of observed and modelled runoff but also highlighting some deficiencies in capturing peak flows.

A more comprehensive overview on model performance is provided in Figs. 6 and 7, which show the spatial distribution of all considered skill scores of the selected RFM for both the cross validation in time and for the cross validation in space. Table 1 lists the median performance for both cross validation experiments. In addition, the boxplots in Figs. 6 and 7 allow comparing the distribution of the performance of all considered modelling setups (Eqs. 1-3) to the performance of LSM simulations. For the sake of brevity the following description of the results is limited to the selected RFM with full atmospheric forcing.
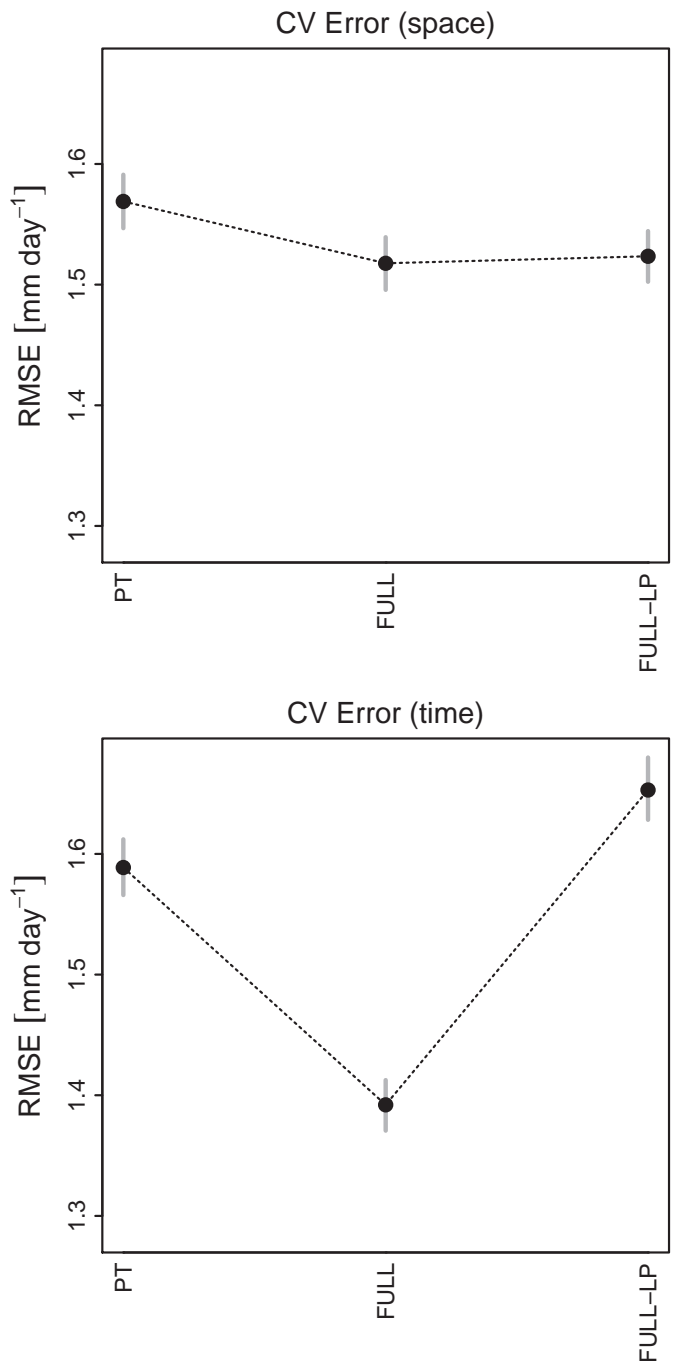

Figure 4. Model selection: RMSE of the three considered model setups (PT: precipitation and temperature forcing. FULL: full atmospheric forcing. FULL-LP: full atmospheric forcing and land parameters; see Sect. 3.1). RMSE is estimated for both the cross validation in space and the cross validation in time (see Sect. 3.3.1).

Overall, there are no clear spatial patterns in $S_{\text {seas }}$ and MEf, which are on average positive for both cross validation experiments. This shows that the RFM is at most locations a better estimator of monthly runoff variability than mere repetitions of the climatology. Interestingly the RFM also outperforms all LSMs under consideration with respect to $S_{\text {seas }}$ and MEf.

On average, the relative BIAS of the RFM is slightly negative, indicating a tendency of the model to underestimate monthly runoff rates in the considered catchments. Generally the relative bias of the considered LSMs is comparable to the RFM bias, highlighting their similar mean annual runoff rates. 

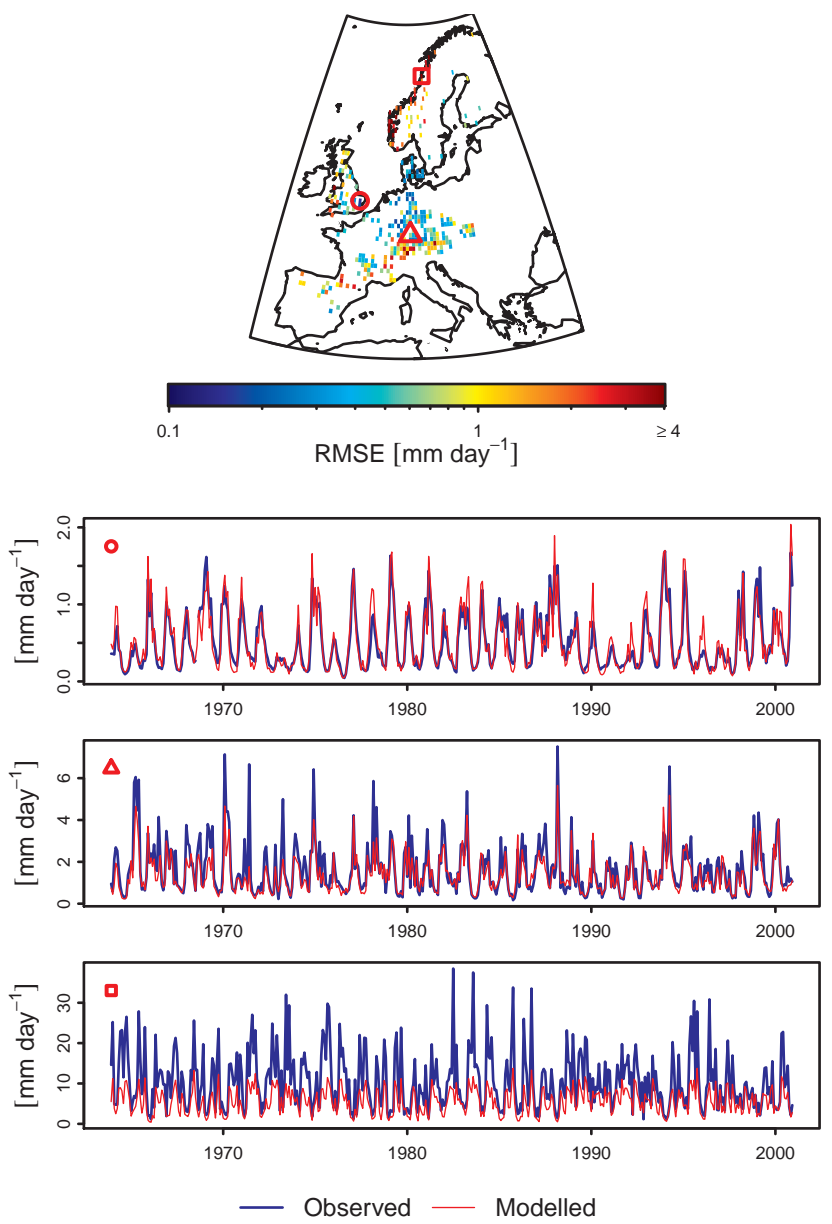

Figure 5. Example time series. The top panel shows the RMSE of the random forest model with full atmospheric forcing (Eq. 2). The symbols mark the grid cells with the lowest (circle), median (triangle) and highest (square) RMSE. The corresponding time series of observed and modelled monthly runoff are shown in the lower panels.

The median coefficient of determination, $R^{2}$, between the RFM and the observed runoff rates are high and there are no pronounced spatial patterns for both cross validation experiments. This indicates the capability of the empirical model to capture the temporal evolution of runoff in Europe. Also, with respect to $R^{2}$, the selected RFM is closer to the observations than any LSM under consideration. The remarkably high coefficient of determination between the observed and modelled mean annual cycles, Climatology- $R^{2}$, of the RFM are contrasted by the relatively low correlations of the LSMs. This result highlights the RFM's ability to capture the seasonality of runoff, but also points towards the fact that the considered LSMs have issues with reproducing this feature. The median coefficient of determination of observed and modelled monthly runoff anomalies, Anomaly- $R^{2}$, reach only intermediate levels showing the RFM's capability to estimate anomalies is somewhat lower than capturing the sea-
Table 1. Median grid-cell performance of the random forest model with full atmospheric forcing (Eq. 2).

\begin{tabular}{lrr}
\hline & CV in Space & CV in Time \\
\hline$S_{\text {seas }}$ & 0.31 & 0.27 \\
MEf & 0.64 & 0.61 \\
BIAS & -0.08 & -0.09 \\
$R^{2}$ & 0.78 & 0.73 \\
$R_{\text {clim }}^{2}$ & 0.93 & 0.94 \\
$R_{\text {ano }}^{2}$ & 0.71 & 0.60 \\
\hline
\end{tabular}

sonal cycle. For Anomaly $R^{2}$ the difference between the RFM and the LSMs is less pronounced.

To assess whether model performance is dependent on climate conditions, a correlation analysis was conducted relating the spatial patterns in model performance to annual means of runoff, precipitation and temperature. Overall, the results (Fig. 8) indicate that there is little influence of mean climate on model performance (all correlations being $|r|<$ 0.5). Nevertheless Fig. 8 also suggests that there is some dependence of the relative bias on mean annual runoff. In addition, Fig. 8 suggests a possible link between mean temperature and Anomaly- $R^{2}$.

Finally, the difference between the cross validation in time and the cross validation in space is interesting to note. Overall, the RFM has a slightly higher performance for the cross validation in space. This shows that the RFM is more skilful in estimating runoff dynamics at ungauged locations than at times without observations.

\subsubsection{Basin-scale validation}

Although the RFM was initially developed to estimate gridscale runoff it can also be used to derive first-order estimates of monthly river discharge. For this, monthly runoff from all grid cells within a river basin are spatially averaged for each time step. The resulting series of estimated monthly river discharge correspond reasonably well to the observed values (Figs. 9, 10). The RFM is also closer to the observations than the considered LSMs with respect to the majority of the performance metrics $\left(S_{\text {seas }}\right.$, MEf, $R^{2}$ and Anomaly- $R^{2}$ ). However, in most river basins, two LSMs show a similar ability in capturing the seasonal cycle of river discharge (Climatology$R^{2}$ ) and the RFM is outperformed by the LSMs with respect to the relative bias.

\subsubsection{Long-term mean evapotranspiration}

The long-term difference between the WFD precipitation and RFM runoff was compared to a benchmark estimate of land evapotranspiration from the LandFlux-EVAL synthesis product (Mueller et al., 2013). Figure 11 shows the longterm mean evapotranspiration derived from the RFM and the LandFlux-EVAL synthesis product. Overall, the two prod- 

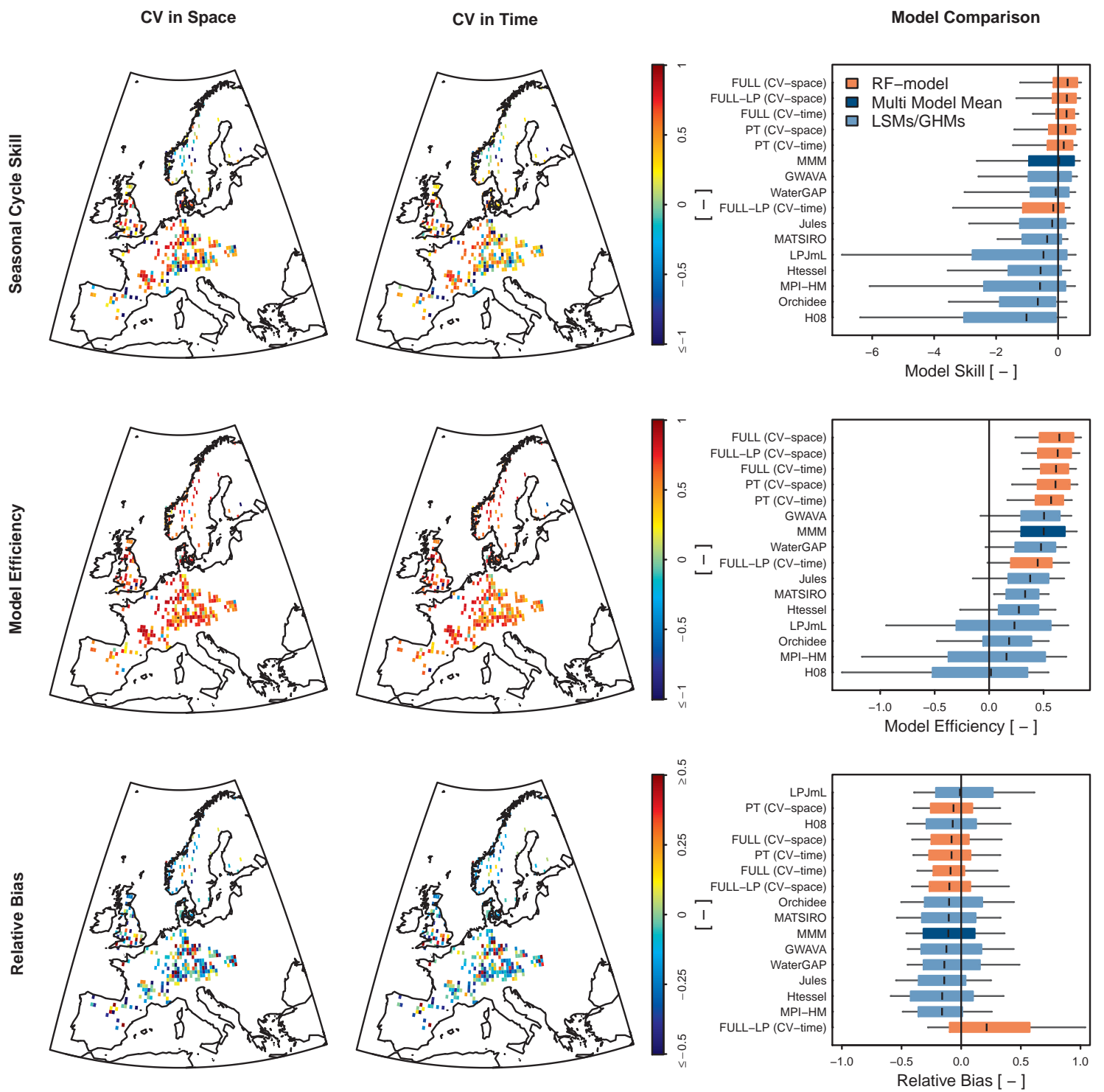

Figure 6. Grid-cell-scale validation (A): spatial distribution of the performance of the random forest model with full atmospheric forcing (Eq. 2), measured with different skill scores and derived for the cross validation (CV) in time and the CV in space experiment. The boxplots allow us to compare the performance distribution of all tested random forest models (Eqs. 1-3) with runoff simulations from a multi-model ensemble of LSMs. The individual boxes are ordered according to the median performance, such that the best performing model ranks highest.

ucts agree well $\left(R^{2}=0.66\right)$ and the RFM-based estimate lies in the majority of the cases within the uncertainty bounds of the LandFlux-EVAL product. Note that the RFM estimate does have small negative values in some parts of Scandinavia.

In these cases, the average amount of runoff predicted by the RFM is larger than the average precipitation provided by the WFD. This inconsistency does already emerge for the raw data entering the analysis. This has already been noted by Gudmundsson et al. (2012b), who found that the longterm mean runoff coefficient $\bar{Q} / \bar{P}$ computed from streamflow observations and WFD precipitation in Scandinavia is larger than one, suggesting that the WATCH forcing data underestimate precipitation in this region. In addition, Kauffeldt et al. (2013) conclude that gridded precipitation products often underestimate precipitation in regions affected by snow undercatch. The RFM is able to account for this bias and consequently the long-term mean difference between the WFD precipitation and estimated runoff is negative. This artefact is an intrinsic feature of the forcing data and only the development of unbiased precipitation estimates would resolve this inconsistency. 

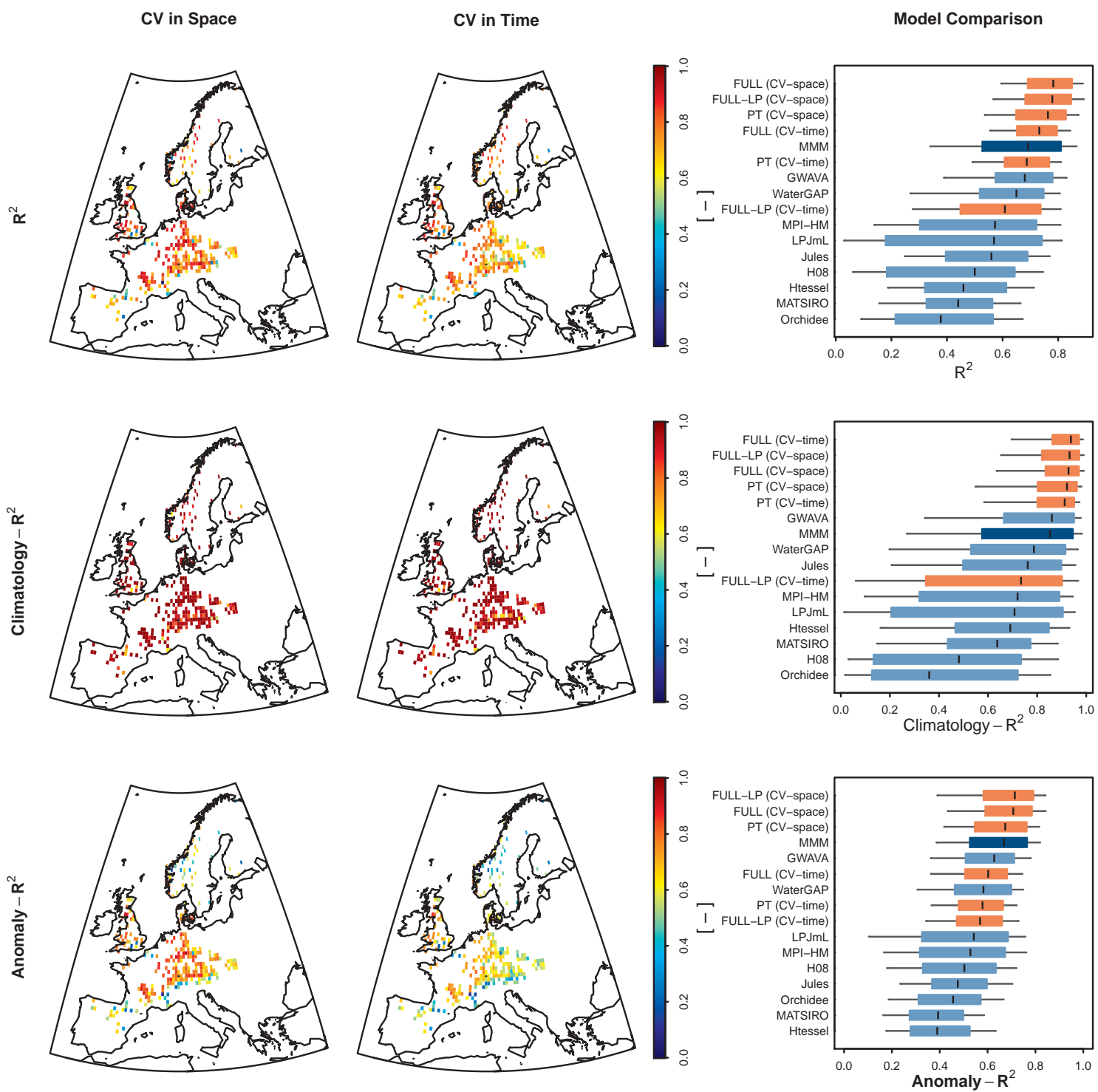

Figure 7. Grid-cell-scale validation (B): same as Fig. 6 but for different skill scores.

\subsection{Example applications}

\subsubsection{Drought monitoring}

The RFM-based gridded runoff estimates can for example be used to monitor surface water availability in Europe. While the monthly resolution may limit its ability to capture flash floods, it is still suitable for observing slowly evolving phenomena that are relevant for water resources management such as droughts. In Europe, 1976 is documented as a year with one of the most severe droughts of the twentieth century (Zaidman et al., 2002; Briffa et al., 2009; Tallaksen and Stahl, 2014). The severity of this drought is illustrated in Fig. 12. Overall, the runoff rates are low in large parts of Europe reaching values well below $1 \mathrm{~mm} \mathrm{~d}^{-1}$. Accordingly, monthly standardised runoff anomalies are negative in most parts of the continent and the extreme departures from normal conditions in southern England, France and central Europe corresponds to previously reported observations (Zaidman et al., 2002). As in Zaidman et al. (2002), runoff rates were log-transformed before standardisation, to account for the skewed distribution of the data.

\subsubsection{A runoff climatology for Europe}

Figure 13 shows a runoff climatology for Europe that is based on the RFM-based runoff estimates. The spatial pattern of the mean annual runoff rates highlights regions with abundant water availability in central and northern Europe. These are contrasted by low runoff rates in southern and eastern Europe. The maps displaying the month with the maximum and the month with the minimum of the mean annual cycle cap- 

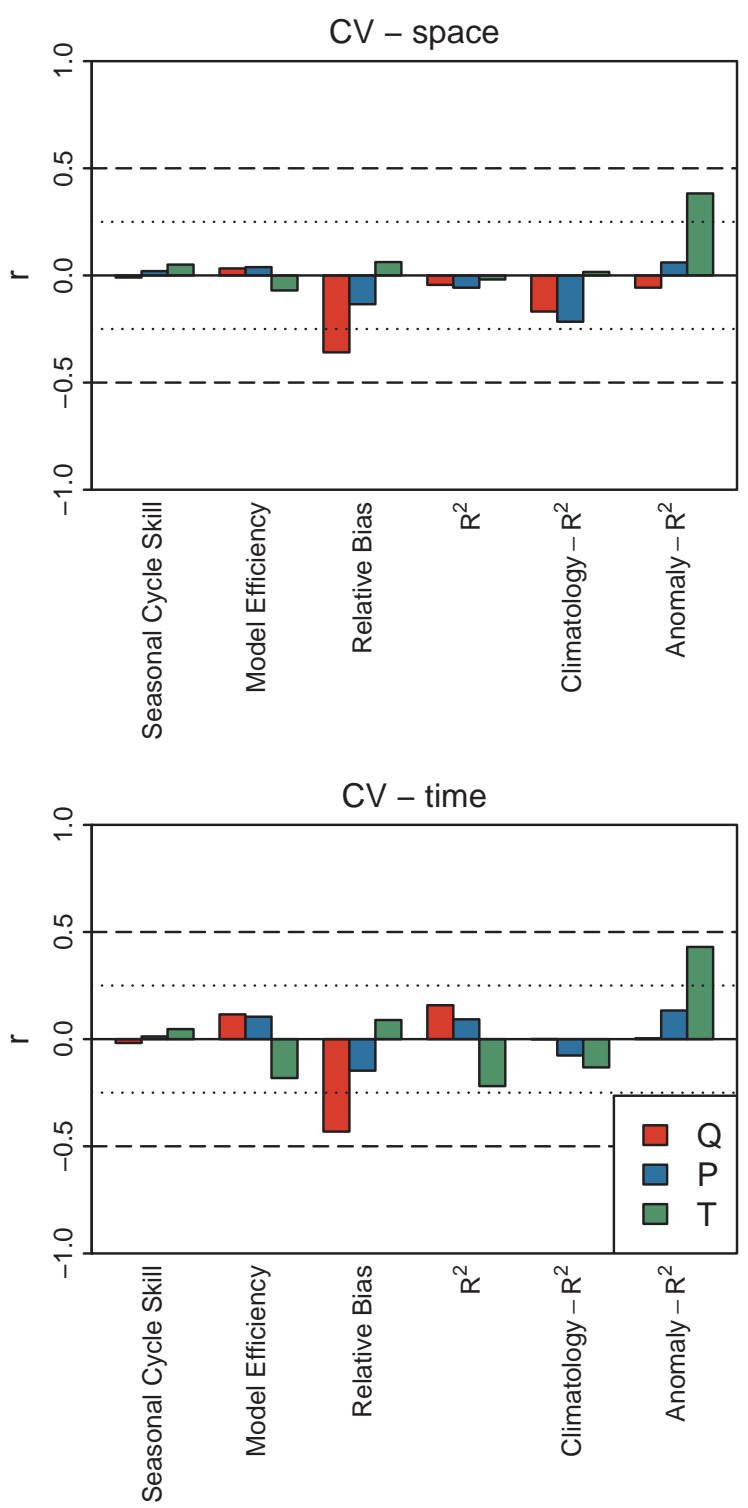

Figure 8. Dependence of model skill on climatic conditions: correlation between grid-cell-level performance of the random forest model with full atmospheric forcing and mean climatic conditions ( $Q$ : mean annual runoff; $P$ : mean annual precipitation; $T:$ mean annual temperature). Horizontal lines at $r= \pm 0.25$ and $r= \pm 0.5$ are included as a visualisation aid. Spatial patterns of the performance metrics are shown in Figs. 6 and 7.

ture the contrasting influence of snow and evapotranspiration dynamics on runoff in Europe. On the one hand, snow accumulation leads to low flows in the winter months of the cold regions (high latitudes and high altitudes) and corresponding spring floods when the water stored as snow is released. On the other hand, evapotranspiration rates follow the seasonality of the atmospheric water demand, leading to minimum runoff rates throughout late summer in large parts of central

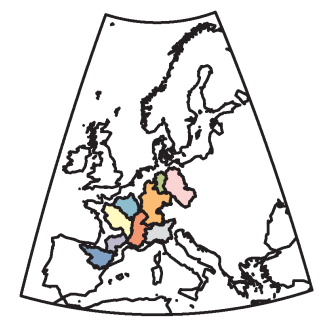

$\square$ Ebro

$\square$ Elbe

$\square$ Garonne

$\square$ Loire

$\square$ Po

$\square$ Rhine

$\square$ Rhone

$\square$ Seine

$\square$ Weser
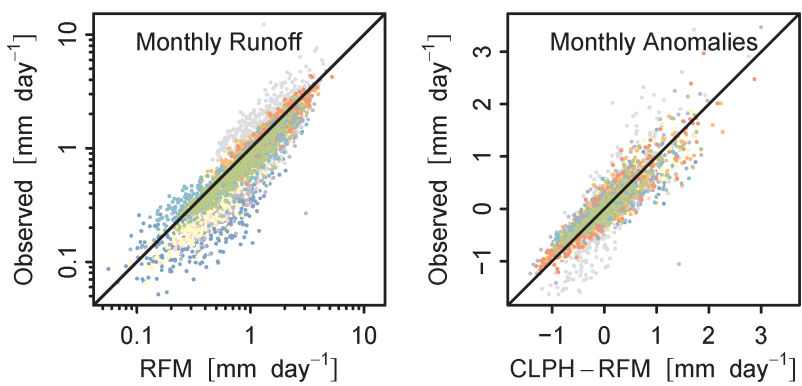

Figure 9. Basin-scale validation (A): top, nine continental-scale river basins used for model validation. Bottom, comparison between observed monthly river discharge to river discharge estimates derived from the random forest model with full atmospheric forcing (left) and comparison between observed and modelled monthly discharge anomalies (right). The similarity between observed an modelled river discharge is quantified in Fig. 10.

and southern Europe and winter floods in the west of the continent.

\section{Discussion}

\subsection{Model selection and overfitting}

The fact that increasing the model complexity, from a model that considers only atmospheric forcing (Eq. 2) to a model taking land parameters into account (Eq. 3), deteriorates model performance points towards issues with overfitting. Overfitting is referred to instances where the statistical model is fitted to random fluctuations (errors) instead of the true underlying relationship. This in turn leads to a reduction of the predictive power of the resulting model. As any machine learning technique, random forests are prone to overfitting, most likely in instances where the number of input variables that have no explanatory power increases (Hastie et al., 2009). In the context of this study, the fact that the inclusion of selected land parameters deteriorates the model's performance therefore suggests that they have little or no explanatory power for continental-scale runoff dynamics.

\subsection{Model performance}

The reasonable performance of the selected RFM with respect to (1) grid-cell runoff, (2) discharge from continen- 

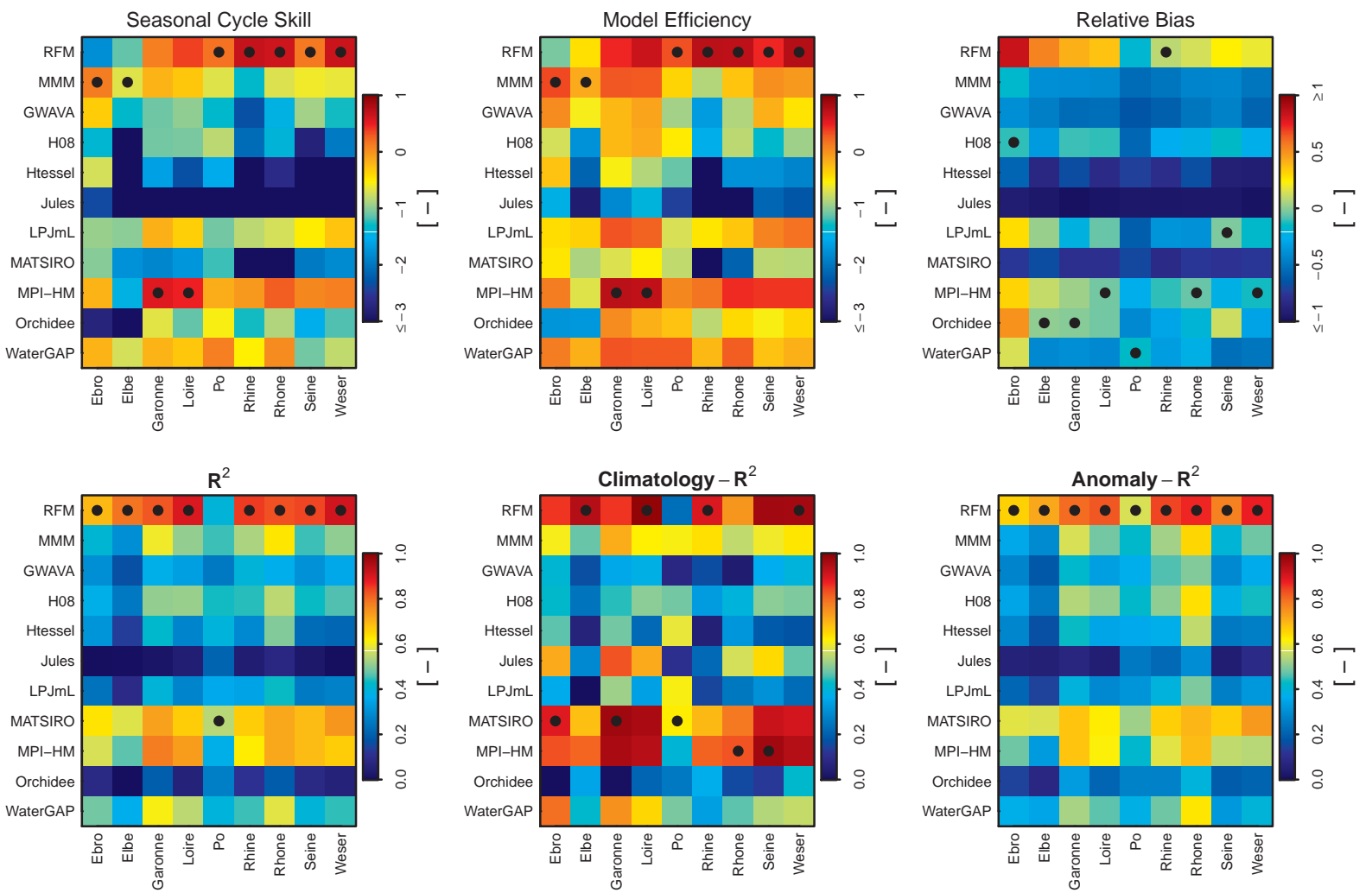

Figure 10. Basin-scale validation (B): performance of the random forest model with full atmospheric forcing compared to the performance of the considered LSMs. Model performance is assessed with respect to continental-scale river discharge, quantified using six different performance metrics. The best performing model for each river is marked by a dot.

tal drainage basins and (3) large-scale evapotranspiration demonstrates the fidelity of the RFM, also out of its expected comfort zone. The results from the cross validation show that the performance of the RFM reaches satisfactory levels, indicating that the employed technique is suitable for estimating monthly runoff at ungauged locations. Despite the fact that the selected RFM does not consider locally varying land parameters, the median performance measures lie within the range of other studies focusing on the prediction of monthly runoff at ungauged locations (Duan et al., 2006; Xia et al., 2012; Kumar et al., 2013; Blöschl et al., 2013).

The fact the RFM outperformed the considered LSMs with respect to most performance metrics (Figs. 6, 7, 10) shows that the RFM-based runoff estimates are closer to the observations than the considered LSMs with the exception of its mean bias. This possibly indicates that the considered LSMs have been optimised with respect to the mean continental river discharge, which might have introduced compensating errors in other features such as the seasonal cycle. Albeit a full explanation of the generally low performance of the LSMs lies beyond the scope of this study, it is noteworthy that the differences between the RFM and the LSMs are most pronounced for the correlation between the observed and modelled mean seasonal cycles $\left(R_{\text {clim }}^{2}\right)$. This issue has been previously reported (Gudmundsson et al., 2012b) and suggests that the LSMs may have deficiencies in capturing processes that govern the seasonality of runoff, such as evapotranspiration and snow dynamics.

\subsection{Factors dominating large-scale terrestrial water dynamics}

The results of the model selection procedure (Fig. 4) do not only allow identifying the model setup that is best suited for estimating gridded monthly runoff in Europe but also provides interesting clues on the optimal description of largescale terrestrial water dynamics. The finding that the model forced by precipitation and temperature only is outperformed by the model considering the full atmospheric forcing, highlights the importance of the remaining atmospheric variables on terrestrial water dynamics. Among the factors that are likely to be important are the snowfall rate and drivers of evapotranspiration (e.g. radiation, humidity and wind speed). Nevertheless, the performance difference between these two modelling setups is relatively small if compared to the performance of the LSMs. This shows that gridded precipitation and temperature may be sufficient for estimating continentalscale runoff dynamics with a reasonable degree of accuracy. 

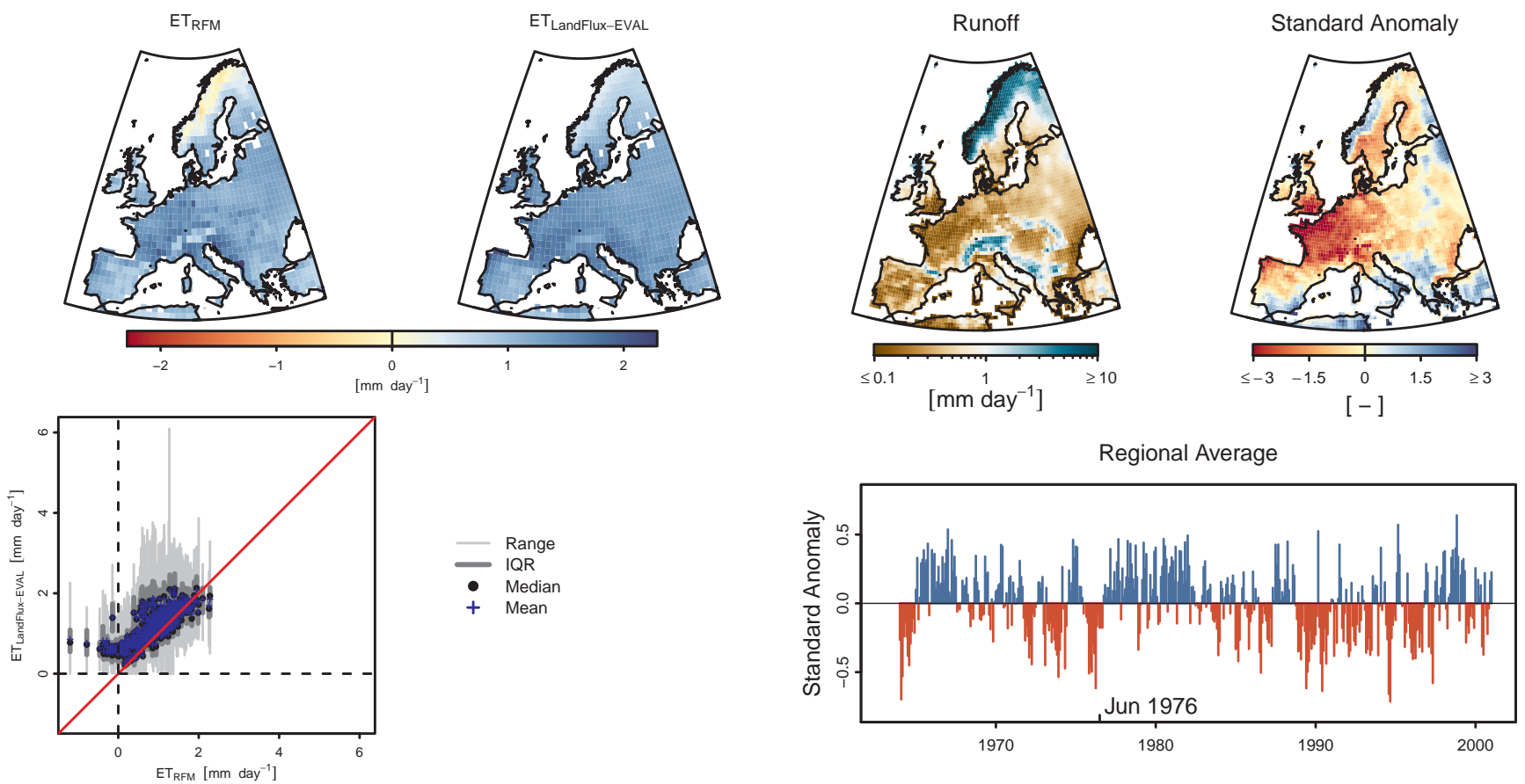

Figure 11. Comparison of mean evapotranspiration (1989-1995) derived from the random forest model with full atmospheric forcing and the LandFlux-EVAL synthesis product. Top left: mean evapotranspiration computed as the mean difference between precipitation and runoff derived from the RFM. Top right: mean evapotranspiration from the LandFlux-EVAL synthesis product (Mueller et al., 2013). Bottom: comparison of the RFM and the LandFluxEVAL estimates of mean evapotranspiration. The vertical bars denote the interquartile range (IQR) and the range of all 40 data sets entering the LandFlux-EVAL product. The points and crosses indicate the median and mean evapotranspiration of the LandFluxEVAL product.

It is surprising that the inclusion of location specific land parameters did not improve the gridded runoff estimate. The fact that the spatial cross validation errors of the models with and without land parameters (Eqs. 2-3 respectively) is not distinguishable implies that the influence of soil texture and topography on monthly runoff could not be detected. This, combined with previous results showing that signatures of runoff dynamics (Gudmundsson et al., 2011b; Sawicz et al., 2011; Ye et al., 2012; Yaeger et al., 2012; Szolgayova et al., 2014) as well as calibrated model parameters (van Werkhoven et al., 2008; Merz et al., 2011) are primarily controlled by climatic conditions, raises questions on the influence of location specific land parameters. In other words, one could speculate that the control of local variations of land parameters on large-scale terrestrial water dynamics may not be detectable, as their influence is overruled by atmospheric forcing. This is discussed in more detail in the following section.

Figure 12. The 1976 drought in Europe. The top left panel shows the monthly runoff rate in June 1976. The top right panel shows the corresponding standardised runoff anomalies. The bottom panel shows the time series of the spatial average of standardised runoff anomalies for the entire region under investigation.

\subsection{Scale dependency and implications for model development}

The fact that the influence of the considered land parameters did not improve the skill of the presented model raises interesting questions regarding the role of locally varying land parameters on terrestrial water dynamics. A likely explanation of this feature is related to the spatiotemporal resolution at which the machine learning model is applied, i.e. that locally varying land parameters may only have a minor influence on regional-scale water fluxes. Previous publications have already suggested that the influence of land cover change on floods and droughts is more pronounced on small scales (e.g. Blöschl et al., 2007) and that locally varying parameters do only have a minor influence on regional-scale soil moisture simulations (e.g. Robock et al., 1998). Similarly, Oudin et al. (2008) found only a weak empirical influence of land cover on long-term mean annual streamflow. However, an exhaustive assessment of such scale effects is still lacking.

While a complete assessment lies beyond the scope of this study a simple analysis of scale can provide some clues on the spatial and temporal resolution at which the effects of locally varying land parameters on runoff are expected to be detectable. For this we adopt the idea that terrestrial water dynamics has two separate space scales and timescales: a short scale where heterogeneous land properties dominate water dynamics and a large scale where homogeneous features of 

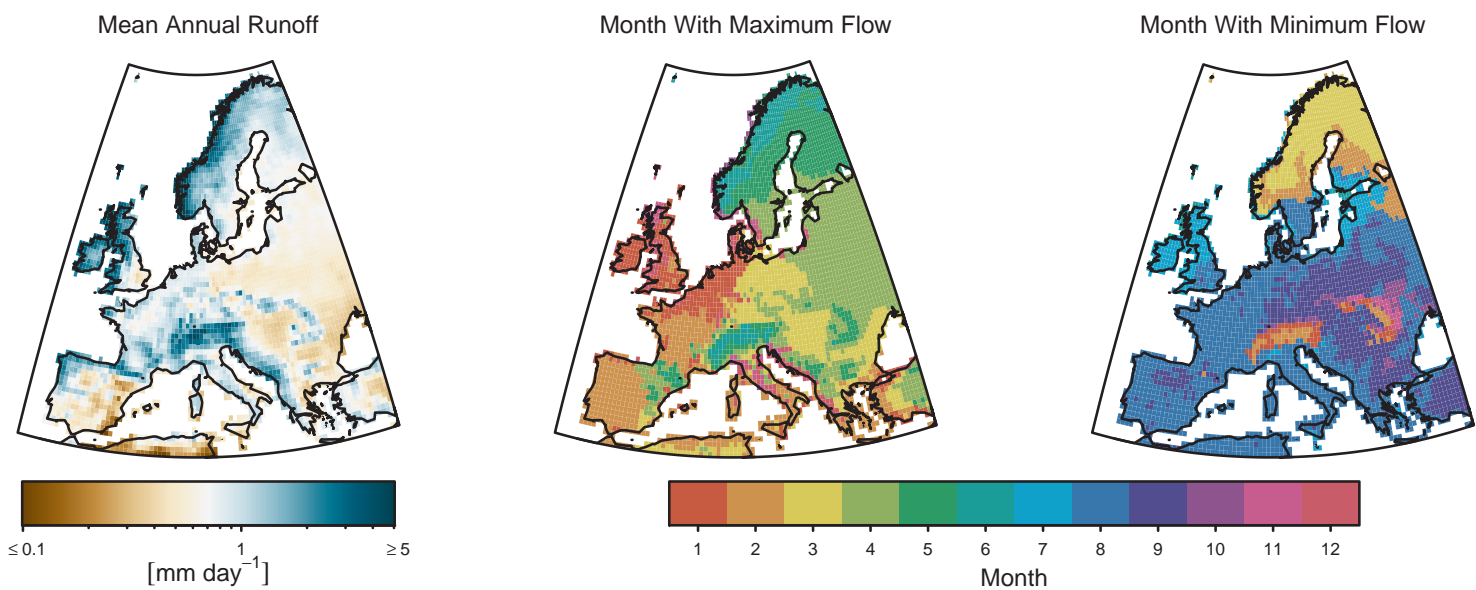

Figure 13. European runoff climatology (1964-2000). Left: long-term mean daily runoff rates. Centre: maximum month of the long-term mean annual cycle. Right: minimum month of the long-term mean annual cycle.

atmospheric forcing are dominating. Following previous suggestions (Vinnikov et al., 1996; Robock et al., 1998; Entin et al., 2000), the separation of timescales can be expressed as a mixture of two autocorrelation functions with exponential decay such that

$r(\tau)=\zeta \exp \left(-\frac{\tau}{T_{\mathrm{L}}}\right)+(1-\zeta) \exp \left(-\frac{\tau}{T_{\mathrm{A}}}\right)$,

where $\tau$ is a time lag, the de-correlation time $T_{\mathrm{L}}$ is the timescale related to heterogeneous land properties, $T_{\mathrm{A}}$ the timescale related to the atmospheric forcing and $\zeta \in[0,1]$ is the fraction of variance related to $T_{\mathrm{L}}$. Note also that $T_{\mathrm{L}}<T_{\mathrm{A}}$. Similarly, the separation of space scales can be expressed as

$r(\lambda)=\eta \exp \left(-\frac{\lambda}{L_{\mathrm{L}}}\right)+(1-\eta) \exp \left(-\frac{\lambda}{L_{\mathrm{A}}}\right)$

where $\lambda$ is the lag distance, $L_{\mathrm{L}}$ is the length scale related to heterogeneous land properties, $L_{\mathrm{A}}$ the length scale related to the atmospheric forcing and $\eta \epsilon[0,1]$ is the fraction of variance related to $L_{\mathrm{L}}$.

While the abovementioned separation of scales has been developed and is well documented for soil moisture (Vinnikov et al., 1996; Robock et al., 1998; Entin et al., 2000; Crow et al., 2012; Mittelbach and Seneviratne, 2012), its validity for other variables is less clear. Therefore, we asses the applicability of Eqs. (8) and (9) for the considered streamflow observations in Europe. (Details on the estimation of space scales and timescales are summarised in Appendix A.) Figure 14 shows the estimated temporal and spatial correlation functions for runoff in Europe and Table 2 reports the parameters of Eqs. (8) and (9) fitted to the data. Overall, the small $p$ values of all parameters show that the hypothesised separation of scales is supported by observations. The timescale related to heterogeneous land parameters, $T_{\mathrm{L}}$, is approximately 1 week, which is well below the monthly resolution of the statistical model presented in this study. Similarly, the length scale related to land parameters, $L_{\mathrm{L}}$, is found to be $\leq 10 \mathrm{~km}$, being substantially smaller than the edge length of the $0.5^{\circ}$ grid cells. The results of this analysis of scales hence suggest that the effect of small-scale variations in land parameters on runoff dynamics may only be detectable for models with spatial and temporal resolutions much higher than the one considered in this study. This is also consistent with the results of the model identification procedure, which could not find a significant improvement of model performance with the inclusion of land parameters for the considered, coarse, spatiotemporal resolution.

\section{Conclusions and outlook}

This study introduced a framework for estimating runoff on regular space-time grids in large spatial domains. The framework is based on the assumption that runoff at any location in space can be modelled as a function of gridded predictors, including both atmospheric variables and land parameters. While the framework has been applied to estimate monthly runoff on a $0.5^{\circ}$ grid in Europe it can in principle be applied to finer spatial and temporal resolutions. The results from both model selection and model validation show that the model is capable of estimating monthly runoff dynamics at locations that were not used for model identification with a reasonable degree of accuracy. These results also show that the derived data are consistent with other variables of the terrestrial water cycle, which increases the confidence in the validity of the gridded runoff estimates. Such grids allow mapping historical runoff dynamics, providing first-order estimates on its past evolution at any location in space, even if no ground observations are available. This is, for example, interesting in regions where no regular updates of streamflow archives exist (for Europe see e.g. Viglione et al., 2010). In such regions one could exploit the presented methodology to 
Table 2. Temporal and spatial scales of daily runoff in Europe: estimate, standard error and $p$ value $(t$ test) of the scaling models (Eqs. 8, 9) fitted to observed temporal and spatial correlation functions using nonlinear least squares regression. Note that the lower limit of $L_{\mathrm{L}}$ was set to the resolution of the empirical spatial correlation function $(10 \mathrm{~km})$.

\begin{tabular}{lrrr|rrr}
\hline & & Temporal & \multicolumn{3}{c}{ Spatial } \\
& $\zeta[-]$ & $T_{\mathrm{L}}$ [days] & $T_{\mathrm{A}}$ [days] & $\eta[-]$ & $L_{\mathrm{L}}[\mathrm{km}]$ & $L_{\mathrm{A}}[\mathrm{km}]$ \\
\hline Estimate & 0.50 & 7.4 & 68.3 & 0.51 & $\leq 10$ & 180.5 \\
Standard error & $3.8 \times 10^{-3}$ & 0.1 & 0.6 & 0.04 & 2.9 & 19.6 \\
$p$ value & $<0.001$ & $<0.001$ & $<0.001$ & $<0.001$ & 0.002 & $<0.001$ \\
\hline
\end{tabular}
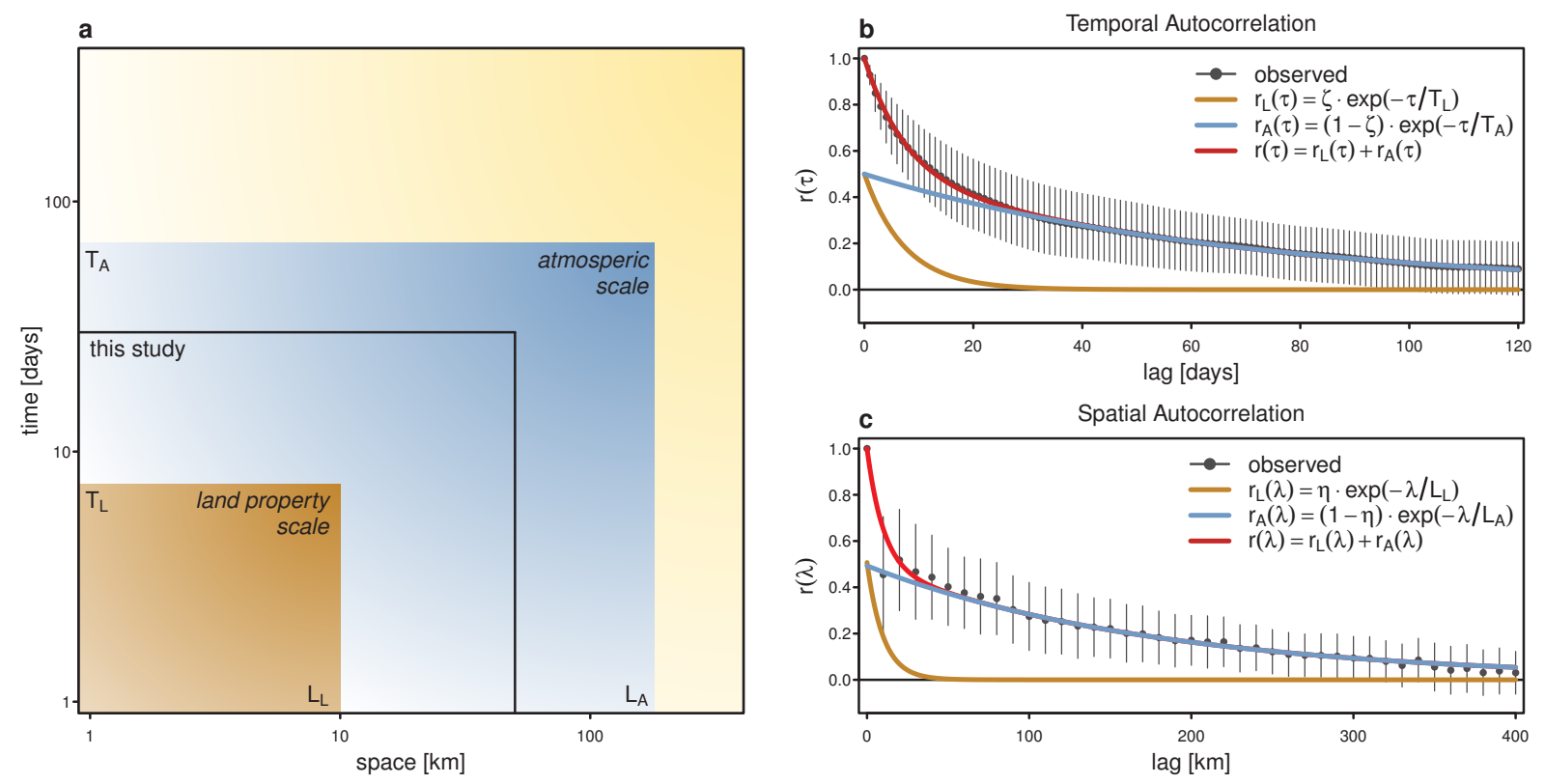

Figure 14. Time- and space scales of runoff in Europe. (a) Empirical results suggest that runoff in Europe has two space scales and timescales. A small scale ( $T_{\mathrm{L}}$ : timescale; $L_{\mathrm{L}}$ : space scale), at which runoff dynamics is strongly influenced by locally varying land properties, and a large scale ( $T_{\mathrm{A}}$ : timescale; $L_{\mathrm{A}}$ : space scale) at which runoff dynamics is dominated by atmospheric forcing. Both the spatial and temporal resolution of this study are located well above the scales at which land properties are expected to have a strong influence on runoff dynamics. (b, c) Small and large scales are estimated from observed autocorrelations of daily runoff anomalies in Europe. Vertical bars denote the standard deviation of the observed autocorrelation. See text for details.

provide estimates of runoff for the years in which the station observations are not yet available.

Although the skill of the proposed method is reasonable and in line with previously published results (Duan et al., 2006; Xia et al., 2012; Kumar et al., 2013; Blöschl et al., 2013), there is still room for improving future estimates of runoff dynamics in Europe. Possible extensions of the presented analysis, each requiring an independent research effort, may focus on one of the following themes.

1. Uncertainty of the considered data: the considered atmospheric forcing data and the land parameters depend both on in situ observations as well as on the methods used to derive estimates of the respective variables on a regular spatial grid. Unfortunately, the uncertainty of the observations and the estimation procedures is often not documented in sufficient detail. However, sev- eral studies suggest that both the choice of atmospheric forcing data and mapped land parameters (e.g. Teuling et al., 2009; Guillod et al., 2013) can have pronounced impacts on simulation results. Similarly, uncertainty estimates of the considered streamflow observations are not available.

2. Limitations of the employed statistical methods: although random forests, like other machine learning techniques, are powerful tools for data driven modelling their application in the presented context may be limited. As other machine learning techniques they are prone to overfitting, implying that noise in the data can obscure possible signals (Hastie et al., 2009). Furthermore, random forests do not explicitly handle spatial and temporal correlation in the data, and the implicit treatment of temporal correlations in equations 1-3 may 
be not sufficient. Consequently, the application of other statistical techniques may improve large-scale estimates of terrestrial water dynamics in the future. Such work could potentially be based on top-kriging approaches (Sauquet et al., 2000; Skøien et al., 2006; Skøien and Blöschl, 2007; Laaha et al., 2013) that account for spatial dependence within the constraints of a channel network.

3. Usage of large river basins for model identification: this study did rely solely on streamflow from small catchments to estimate runoff at the grid-cell scale. However, discharge from large river basins does also carry information, which would be valuable to include into estimates of terrestrial water dynamics. A possible approach for this would be to first route the gridded runoff estimates through a channel network and subsequently apply the procedure suggested by Fekete et al. (2002, 2011) to account for observations from large river basins.

4. The non-exhaustive list of considered land parameters: in this study only the grid-cell slope and information on median grid-cell soil texture were taken into account. Although similar information is regularly used in LSMs, other parameters including the topographic index (Beven and Kirkby, 1979) or information on vegetation structure (Bonan, 2008) may have detectable impacts on large-scale runoff dynamics in Europe.

5. Temporal and spatial resolution: the presented analysis is limited to relatively coarse spatial $\left(0.5^{\circ}\right)$ and temporal (monthly) resolutions, focusing on large-scale phenomena. Obviously this resolution limits the application of the derived data to the analysis of large, continentalscale patterns. To which degree the suggested methodology is capable of capturing small-scale variations of runoff (e.g. flash floods) remains an open question. Further investigations may help to clarify the effect of increasing the spatial and temporal resolutions on modelling runoff at ungauged locations using machine learning tools.

6. Implications for model development: the results from the model identification and validation raised interesting questions regarding the influence of land parameters on continental-scale runoff dynamics. This, paired with an analysis of scales, suggested that the influence of land parameters may only be detectable at model resolutions shorter than 1 week and smaller than $10 \mathrm{~km}$. While this is consistent with the long history of catchment-scale studies, it also raises questions on the optimal design of global-scale models that are built to capture climatological phenomena. In fact, the results suggest that parsimonious physical descriptions, neglecting the influence of small-scale variations in land parameters, may be sufficient to effectively describe terrestrial water dynamics on large scales. In a more formal setting, this can also be expressed as the hypothesis that hydrological variability at any location in space does solely depend on present and past atmospheric forcing - and not on locally varying land parameters. Of course this "Constant Land Parameter Hypothesis" (CLPH) will only be valid in certain circumstances and thus can act as a null hypothesis for testing the influence of selected land parameters on terrestrial water dynamics. This could guide the development of efficient model physics.

In conclusion, we presented a novel approach for estimating the historical space-time evolution of runoff on regular spatial grids. The proposed methodology relies on the power of machine learning techniques to combine in situ observations of runoff with gridded atmospheric variables. For Europe, the resulting runoff estimates compare well with observations and are consistent with other variables of the terrestrial water cycle, including evapotranspiration. Despite some remaining open questions, related e.g. to data uncertainty and spatiotemporal resolution, the derived runoff grid enables a new perspective on features of terrestrial water dynamics that emerge on large spatial scales. This was exemplified by (1) the validation of process-based models, (2) the continuous mapping of runoff climatologies and (3) the analysis of hydrological droughts on large scales. Consequently, the resulting data product allows for a more comprehensive assessment of the historical space-time evolution of runoff in Europe, relaxing the constraints of a limited observation network. 
Appendix A: Estimating space and timescales of streamflow

Following a previous study (Skøien et al., 2003), daily streamflow observations from all catchments were logtransformed and seasonal effects were removed. The deseasonalisation strictly follows recommendations on removal of the seasonal cycle in the mean and the variance using harmonic regression (Hipel and McLeod, 1994; McLeod and Gweon, 2013). Temporal correlation was first estimated for each gauging station separately. The maximum time lag was limited to 120 days to reduce effects of climate-induced interannual variability, which is reportedly strong in the data under investigation (Gudmundsson et al., 2011b). The estimated temporal autocorrelation functions from the individual stations were finally averaged as in previous studies (Entin et al., 2000; Skøien et al., 2003; Vinnikov et al., 1996) to obtain an estimate of the mean autocorrelation function of runoff in Europe. Spatial correlation was estimated using Moran's I (Moran, 1950; Legendre and Legendre, 1998) for each time step separately with a spatial bin width of $10 \mathrm{~km}$. This bin width is a compromise between having enough station pairs per bin and the ability to resolve small-scale processes (the first bin contains 31 pairs, the median number of pairs is 490). The analysis of spatial correlation was limited to a maximum lag distance of $400 \mathrm{~km}$ to reduce the effect of large-scale climate gradients, which impact European runoff dynamics (Gudmundsson et al., 2011a, b). Finally, the spatial correlation functions were then averaged over all time steps, resulting in an estimate of mean spatial correlation for the time period under investigation. 
Acknowledgements. This research contributes to the European Union (FP7) funded project DROUGHT-R\&SPI (contract no. 282769). Partial support of the ERC DROUGHT-HEAT project (contract no. 617518) is acknowledged. The effort to assemble the European Water Archive (EWA) by the UNESCO IHP VII FRIEND programme, the data management by the GRDC, the generation of the WFD and the LSM ensemble by members of the European Union WATCH project (FP6) are gratefully acknowledged.

Edited by: V. Andréassian

\section{References}

Arnell, N. W.: Grid mapping of river discharge, J. Hydrol., 167, 39 56, doi:10.1016/0022-1694(94)02626-M, 1995.

Baldocchi, D.: TURNER REVIEW No. 15. "Breathing" of the terrestrial biosphere: lessons learned from a global network of carbon dioxide flux measurement systems, Aust. J. Bot., 56, 1-26, doi:10.1071/BT07151, 2008.

Balsamo, G., Albergel, C., Beljaars, A., Boussetta, S., Brun, E., Cloke, H., Dee, D., Dutra, E., Muñoz-Sabater, J., Pappenberger, F., de Rosnay, P., Stockdale, T., and Vitart, F.: ERAInterim/Land: a global land surface reanalysis data set, Hydrol. Earth Syst. Sci., 19, 389-407, doi:10.5194/hess-19-389-2015, 2015.

Beck, H. E., van Dijk, A. I. J. M., Miralles, D. G., de Jeu, R. A. M., Bruijnzeel, L. A., McVicar, T. R., and Schellekens, J.: Global patterns in base flow index and recession based on streamflow observations from 3394 catchments, Water Resour. Res., 49, $7843-$ 7863, doi:10.1002/2013WR013918, 2013.

Beven, K. J. and Kirkby, M. J.: A physically based, variable contributing area model of basin hydrology, Hydrolog. Sci. J., 24, 43-69, doi:10.1080/02626667909491834, 1979.

Bishop, C. M.: Pattern Recognition and Machine Learning, Information Science and Statistics, Springer, 2006.

Blöschl, G., Ardoin-Bardin, S., Bonell, M., Dorninger, M., Goodrich, D., Gutknecht, D., Matamoros, D., Merz, B., Shand, P., and Szolgay, J.: At what scales do climate variability and land cover change impact on flooding and low flows?, Hydrol. Process., 21, 1241-1247, doi:10.1002/hyp.6669, 2007.

Blöschl, G., Sivapalan, M., Wagener, T., Viglione, A., and Savenije, H., eds.: Runoff Prediction in Ungauged Basins: Synthesis Across Processes, Places and Scales, Cambridge University Press, 2013.

Bonan, G. B.: Ecological Climatology: Concepts and Applications, Cambridge University Press, 2 Edn., 2008.

Breiman, L.: Random Forests, Mach. Learn., 45, 5-32, doi:10.1023/A:1010933404324, 2001.

Briffa, K. R., van der Schrier, G., and Jones, P. D.: Wet and dry summers in Europe since 1750: evidence of increasing drought, Int. J. Clim., 29, 1894-1905, doi:10.1002/joc.1836, 2009.

Ciais, P., Reichstein, M., Viovy, N., Granier, A., Ogee, J., Allard, V., Aubinet, M., Buchmann, N., Bernhofer, C., Carrara, A., Chevallier, F., De Noblet, N., Friend, A. D., Friedlingstein, P., Grunwald, T., Heinesch, B., Keronen, P., Knohl, A., Krinner, G., Loustau, D., Manca, G., Matteucci, G., Miglietta, F., Ourcival, J. M., Papale, D., Pilegaard, K., Rambal, S., Seufert, G., Soussana, J. F., Sanz, M. J., Schulze, E. D., Vesala, T., and Valentini, R.: Europe-wide reduction in primary productivity caused by the heat and drought in 2003, Nature, 437, 529-533, doi:10.1038/nature03972, 2005.

Crow, W. T., Berg, A. A., Cosh, M. H., Loew, A., Mohanty, B. P., Panciera, R., de Rosnay, P., Ryu, D., and Walker, J. P.: Upscaling sparse ground-based soil moisture observations for the validation of coarse-resolution satellite soil moisture products, Rev. Geophys., 50, RG2002, doi:10.1029/2011RG000372, 2012.

de Jeu, R., Wagner, W., Holmes, T., Dolman, A., van de Giesen, N., and Friesen, J.: Global Soil Moisture Patterns Observed by Space Borne Microwave Radiometers and Scatterometers, Surv. Geophys., 29, 399-420, doi:10.1007/s10712-008-9044-0, 10.1007/s10712-008-9044-0, 2008.

de Linage, C., Famiglietti, J. S., and Randerson, J. T.: Statistical prediction of terrestrial water storage changes in the Amazon Basin using tropical Pacific and North Atlantic sea surface temperature anomalies, Hydrol. Earth Syst. Sci., 18, 2089-2102, doi:10.5194/hess-18-2089-2014, 2014.

Dettinger, M. and Diaz, H.: Global Characteristics of Stream Flow Seasonality and Variability, J. Hydrometeorol., 1, 289-310, doi:10.1175/1525-7541(2000)001<0289:GCOSFS >2.0.CO;2, 2000.

Dirmeyer, P. A., Gao, X., Zhao, M., Guo, Z., Oki, T., and Hanasaki, N.: GSWP-2: Multimodel Analysis and Implications for Our Perception of the Land Surface, B. Am. Meteorol. Soc., 87, 13811397, doi:10.1175/BAMS-87-10-1381, 2006.

Döll, P., Fiedler, K., and Zhang, J.: Global-scale analysis of river flow alterations due to water withdrawals and reservoirs, Hydrol. Earth Syst. Sci., 13, 2413-2432, doi:10.5194/hess-13-24132009, 2009.

Dorigo, W., Xaver, A., Vreugdenhil, M., Gruber, A., Hegyiová, A., Sanchis-Dufau, A., Zamojski, D., Cordes, C., Wagner, W., and Drusch, M.: Global Automated Quality Control of In Situ Soil Moisture Data from the International Soil Moisture Network, Vadose Zone J., 12, doi:10.2136/vzj2012.0097, 2013.

Duan, Q., Schaake, J., Andréassian, V., Franks, S., Goteti, G., Gupta, H., Gusev, Y., Habets, F., Hall, A., Hay, L., Hogue, T., Huang, M., Leavesley, G., Liang, X., Nasonova, O., Noilhan, J., Oudin, L., Sorooshian, S., Wagener, T., and Wood, E.: Model Parameter Estimation Experiment (MOPEX): An overview of science strategy and major results from the second and third workshops, J. Hydrol., 320, 3-17, doi:10.1016/j.jhydrol.2005.07.031, 2006.

Entin, J. K., Robock, A., Vinnikov, K. Y., Hollinger, S. E., Liu, S., and Namkhai, A.: Temporal and spatial scales of observed soil moisture variations in the extratropics, J. Geophys. Res., 105, 865-877, doi:10.1029/2000JD900051, 2000.

Famiglietti, J. S. and Rodell, M.: Water in the Balance, Science, 340, 1300-1301, doi:10.1126/science.1236460, 2013.

FAO, IIASA, ISRIC, ISSCAS, and JRC: Harmonized World Soil Database (version 1.2), Tech. Rep., FAO, Rome, Italy and IIASA, Laxenburg, Austria, 2012.

Fekete, B., Maurer, T., and Vörösmarty, C. J.: ISLSCP II UNH/GRDC Composite Monthly Runoff, in: ISLSCP Initiative II Collection. Data set, edited by Hall, I., G., F., Collatz, G., Meeson, B., Los, S., de Colstoun, E. B., and Landis, D., Oak Ridge National Laboratory Distributed Active Archive Center, Oak Ridge, Tennessee, USA, doi:10.3334/ORNLDAAC/994, 2011. 
Fekete, B. M., Vörösmarty, C. J., and Grabs, W.: High-resolution fields of global runoff combining observed river discharge and simulated water balances, Global Biogeochem. Cy., 16, 1042, doi:10.1029/1999GB001254, 2002.

Fekete, B. M., Looser, U., Pietroniro, A., and Robarts, R. D.: Rationale for Monitoring Discharge on the Ground, J. Hydrometeorol., 13, 1977-1986, doi:10.1175/JHM-D-11-0126.1, 2012.

Granier, A., Reichstein, M., Bréda, N., Janssens, I., Falge, E., Ciais, P., Grünwald, T., Aubinet, M., Berbigier, P., Bernhofer, C., Buchmann, N., Facini, O., Grassi, G., Heinesch, B., Ilvesniemi, H., Keronen, P., Knohl, A., Köstner, B., Lagergren, F., Lindroth, A., Longdoz, B., Loustau, D., Mateus, J., Montagnani, L., Nys, C., Moors, E., Papale, D., Peiffer, M., Pilegaard, K., Pita, G., Pumpanen, J., Rambal, S., Rebmann, C., Rodrigues, A., Seufert, G., Tenhunen, J., Vesala, T., and Wang, Q.: Evidence for soil water control on carbon and water dynamics in European forests during the extremely dry year: 2003, Agr. Forest Meteorol., 143, 123145, doi:10.1016/j.agrformet.2006.12.004, 2007.

Greve, P., Orlowsky, B., Mueller, B., Sheffield, J., Reichstein, M., and Seneviratne, S. I.: Global assessment of trends in wetting and drying over land, Nat. Geosci., advance online publication, doi:10.1038/ngeo2247, 2014

Guan, K., Pan, M., Li, H., Wolf, A., Wu, J., Medvigy, D., Caylor, K. K., Sheffield, J., Wood, E. F., Malhi, Y., Liang, M., Kimball, J. S., Saleska, S. R., Berry, J., Joiner, J., and Lyapustin, A. I.: Photosynthetic seasonality of global tropical forests constrained by hydroclimate, Nat. Geosci., advance online publication, doi:10.1038/ngeo2382, 2015.

Gudmundsson, L. and Seneviratne, S. I.: A comprehensive drought climatology for Europe (1950-2013), in: Drought: Research and Science-Policy Interfacing, 31-37, CRC Press, doi:10.1201/b18077-7, 2015.

Gudmundsson, L., Tallaksen, L. M., and Stahl, K.: Spatial crosscorrelation patterns of European low, mean and high flows, Hydrol. Process., 25, 1034-1045, doi:10.1002/hyp.7807, 2011a.

Gudmundsson, L., Tallaksen, L. M., Stahl, K., and Fleig, A. K.: Low-frequency variability of European runoff, Hydrol. Earth Syst. Sci., 15, 2853-2869, doi:10.5194/hess-15-28532011, 2011b.

Gudmundsson, L., Tallaksen, L. M., Stahl, K., Clark, D. B., Dumont, E., Hagemann, S., Bertrand, N., Gerten, D., Heinke, J., Hanasaki, N., Voss, F., and Koirala, S.: Comparing Large-Scale Hydrological Model Simulations to Observed Runoff Percentiles in Europe, J. Hydrometeorol., 13, 604-620, doi:10.1175/JHMD-11-083.1, 2012a.

Gudmundsson, L., Wagener, T., Tallaksen, L. M., and Engeland, K.: Evaluation of nine large-scale hydrological models with respect to the seasonal runoff climatology in Europe, Water Resour. Res., 48, W11504, doi:10.1029/2011WR010911, 2012b.

Gudmundsson, L., Rego, F. C., Rocha, M., and Seneviratne, S. I.: Predicting above normal wildfire activity in southern Europe as a function of meteorological drought, Environ. Res. Lett., 9, 084008, doi:10.1088/1748-9326/9/8/084008, 2014.

Guillod, B., Davin, E., Kündig, C., Smiatek, G., and Seneviratne, S. I.: Impact of soil map specifications for European climate simulations, Clim. Dynam., 40, 123-141, doi:10.1007/s00382-0121395-z, 2013.

Haddeland, I., Clark, D. B., Franssen, W., Ludwig, F., Voß, F., Arnell, N. W., Bertrand, N., Best, M., Folwell, S., Gerten, D.,
Gomes, S., Gosling, S. N., Hagemann, S., Hanasaki, N., Harding, R., Heinke, J., Kabat, P., Koirala, S., Oki, T., Polcher, J., Stacke, T., Viterbo, P., Weedon, G. P., and Yeh, P.: Multimodel Estimate of the Global Terrestrial Water Balance: Setup and First Results, J. Hydrometeorol., 12, 869-884, doi:10.1175/2011JHM1324.1, 2011.

Haddeland, I., Heinke, J., Voß, F., Eisner, S., Chen, C., Hagemann, S., and Ludwig, F.: Effects of climate model radiation, humidity and wind estimates on hydrological simulations, Hydrol. Earth Syst. Sci., 16, 305-318, doi:10.5194/hess-16-305-2012, 2012.

Hannah, D. M., Demuth, S., van Lanen, H. A. J., Looser, U., Prudhomme, C., Rees, G., Stahl, K., and Tallaksen, L. M.: Large-scale river flow archives: importance, current status and future needs, Hydrol. Process., 25, 1191-1200, doi:10.1002/hyp.7794, 2011.

Hastie, T., Tibshirani, R., and Friedman, J. H.: The Elements of Statistical Learning - Data Mining, Inference, and Prediction, Second Edition, Springer Series in Statistics, Springer, 2 Edn., 2009.

Hipel, K. and McLeod, A.: Time series modelling of water resources and environmental systems, Vol. 45 of Developments in Water Science, Elsevier, 1994.

Hirschi, M., Seneviratne, S. I., and Schär, C.: Seasonal Variations in Terrestrial Water Storage for Major Midlatitude River Basins, J. Hydrometeorol., 7, 39-60, doi:10.1175/JHM480.1, 2006.

Hirschi, M., Mueller, B., and Seneviratne, S. I.: Using remotely sensed soil moisture for land-atmosphere coupling diagnostics: The role of surface vs. root-zone soil moisture variability, Remote Sens. Environ., 154, 246-252, doi:10.1016/j.rse.2014.08.030, 2014.

Houborg, R., Rodell, M., Li, B., Reichle, R., and Zaitchik, B. F.: Drought indicators based on model-assimilated Gravity Recovery and Climate Experiment (GRACE) terrestrial water storage observations, Water Resour. Res., 48, W07525, doi:10.1029/2011WR011291, 2012.

Hrachowitz, M., Savenije, H. H. G., Blöschl, G., McDonnell, J. J., Sivapalan, M., Pomeroy, J. W., Arheimer, B., Blume, T., Clark, M. P., Ehret, U., Fenicia, F., Freer, J. E., Gelfan, A., Gupta, H. V., Hughes, D. A., Hut, R. W., Montanari, A., Pande, S., Tetzlaff, D., Troch, P. A., Uhlenbrook, S., Wagener, T., Winsemius, H. C., Woods, R. A., Zehe, E., and Cudennec, C.: A decade of Predictions in Ungauged Basins (PUB) - a review, Hydrol. Sci. J., 58, 1198-1255, doi:10.1080/02626667.2013.803183, 2013.

Jung, M., Reichstein, M., and Bondeau, A.: Towards global empirical upscaling of FLUXNET eddy covariance observations: validation of a model tree ensemble approach using a biosphere model, Biogeosciences, 6, 2001-2013, doi:10.5194/bg-6-20012009, 2009.

Jung, M., Reichstein, M., Ciais, P., Seneviratne, S. I., Sheffield, J., Goulden, M. L., Bonan, G., Cescatti, A., Chen, J., de Jeu, R., Dolman, A. J., Eugster, W., Gerten, D., Gianelle, D., Gobron, N., Heinke, J., Kimball, J., Law, B. E., Montagnani, L., Mu, Q., Mueller, B., Oleson, K., Papale, D., Richardson, A. D., Roupsard, O., Running, S., Tomelleri, E., Viovy, N., Weber, U., Williams, C., Wood, E., Zaehle, S., and Zhang, K.: Recent decline in the global land evapotranspiration trend due to limited moisture supply, Nature, 467, 951-954, doi:10.1038/nature09396, 2010.

Jung, M., Reichstein, M., Margolis, H. A., Cescatti, A., Richardson, A. D., Arain, M. A., Arneth, A., Bernhofer, C., Bonal, D., Chen, J., Gianelle, D., Gobron, N., Kiely, G., Kutsch, W., Lasslop, G., 
Law, B. E., Lindroth, A., Merbold, L., Montagnani, L., Moors, E. J., Papale, D., Sottocornola, M., Vaccari, F., and Williams, C.: Global patterns of land-atmosphere fluxes of carbon dioxide, latent heat, and sensible heat derived from eddy covariance, satellite, and meteorological observations, J. Geophys. Res., 116, G00J07, doi:10.1029/2010JG001566, 2011.

Kauffeldt, A., Halldin, S., Rodhe, A., Xu, C.-Y., and Westerberg, I. K.: Disinformative data in large-scale hydrological modelling, Hydrol. Earth Syst. Sci., 17, 2845-2857, doi:10.5194/hess-172845-2013, 2013.

Koster, R. D., Dirmeyer, P. A., Guo, Z., Bonan, G., Chan, E., Cox, P., Gordon, C. T., Kanae, S., Kowalczyk, E., Lawrence, D., Liu, P., Lu, C.-H., Malyshev, S., McAvaney, B., Mitchell, K., Mocko, D., Oki, T., Oleson, K., Pitman, A., Sud, Y. C., Taylor, C. M., Verseghy, D., Vasic, R., Xue, Y., and Yamada, T.: Regions of Strong Coupling Between Soil Moisture and Precipitation, Science, 305, 1138-1140, doi:10.1126/science.1100217, 2004.

Krakauer, N. Y. and Fung, I.: Mapping and attribution of change in streamflow in the coterminous United States, Hydrol. Earth Syst. Sci., 12, 1111-1120, doi:10.5194/hess-12-1111-2008, 2008.

Kumar, R., Livneh, B., and Samaniego, L.: Toward computationally efficient large-scale hydrologic predictions with a multiscale regionalization scheme, Water Resour. Res., 49, 57005714, doi:10.1002/wrcr.20431, 2013.

Laaha, G., Skøien, J. O., Nobilis, F., and Bløschl, G.: Spatial Prediction of Stream Temperatures Using Top-Kriging with an External Drift, Environ. Model. Assess., 18, 671-683, doi:10.1007/s10666-013-9373-3, 2013.

Landerer, F. W. and Swenson, S. C.: Accuracy of scaled GRACE terrestrial water storage estimates, Water Resour. Res., 48, W04531, doi:10.1029/2011WR011453, 2012.

Legendre, P. and Legendre, L.: Numerical ecology, Elsevier New York, 1998.

Liaw, A. and Wiener, M.: Classification and Regression by randomForest, R News, 2, 18-22, 2002.

Loew, A., Stacke, T., Dorigo, W., de Jeu, R., and Hagemann, S.: Potential and limitations of multidecadal satellite soil moisture observations for selected climate model evaluation studies, Hydrol. Earth Syst. Sci., 17, 3523-3542, doi:10.5194/hess-17-35232013, 2013.

McLeod, A. I. and Gweon, H.: Optimal Deseasonalization for Monthly and Daily Geophysical Time Series, Journal of Environmentl Statistics, 4, available at: http://www.jenvstat.org/v04/i11/ (last access: 06 June 2015), 2013.

Merz, R., Parajka, J., and Blöschl, G.: Time stability of catchment model parameters: Implications for climate impact analyses, Water Resour. Res., 47, W02531, doi:10.1029/2010WR009505, 2011

Miralles, D. G., van den Berg, M. J., Gash, J. H., Parinussa, R. M., de Jeu, R. A. M., Beck, H. E., Holmes, T. R. H., Jiménez, C., Verhoest, N. E. C., Dorigo, W. A., Teuling, A. J., and Johannes Dolman, A.: El Niño-La Niña cycle and recent trends in continental evaporation, Nature Clim. Change, 4, 122-126, doi:10.1038/nclimate2068, 2014.

Mittelbach, H. and Seneviratne, S. I.: A new perspective on the spatio-temporal variability of soil moisture: temporal dynamics versus time-invariant contributions, Hydrol. Earth Syst. Sci., 16, 2169-2179, doi:10.5194/hess-16-2169-2012, 2012.
Moran, P. A. P.: Notes on Continuous Stochastic Phenomena, Biometrika, 37, 17-23, 1950.

Mueller, B. and Seneviratne, S. I.: Hot days induced by precipitation deficits at the global scale, P. Natl. Acad. Sci., 109, 12398 12403, doi:10.1073/pnas.1204330109, 2012.

Mueller, B., Hirschi, M., and Seneviratne, S. I.: New diagnostic estimates of variations in terrestrial water storage based on ERA-Interim data, Hydrol. Process., 25, 996-1008, doi:10.1002/hyp.7652, 2011a.

Mueller, B., Seneviratne, S. I., Jimenez, C., Corti, T., Hirschi, M., Balsamo, G., Ciais, P., Dirmeyer, P., Fisher, J. B., Guo, Z., Jung, M., Maignan, F., McCabe, M. F., Reichle, R., Reichstein, M., Rodell, M., Sheffield, J., Teuling, A. J., Wang, K., Wood, E. F., and Zhang, Y.: Evaluation of global observations-based evapotranspiration datasets and IPCC AR4 simulations, Geophys. Res. Lett., 38, L06402, doi:10.1029/2010GL046230, 2011b.

Mueller, B., Hirschi, M., Jimenez, C., Ciais, P., Dirmeyer, P. A., Dolman, A. J., Fisher, J. B., Jung, M., Ludwig, F., Maignan, F., Miralles, D. G., McCabe, M. F., Reichstein, M., Sheffield, J., Wang, K., Wood, E. F., Zhang, Y., and Seneviratne, S. I.: Benchmark products for land evapotranspiration: LandFluxEVAL multi-data set synthesis, Hydrol. Earth Syst. Sci., 17, 3707-3720, doi:10.5194/hess-17-3707-2013, 2013.

Nash, J. E. and Sutcliffe, J. V.: River flow forecasting through conceptual models part I - A discussion of principles, J. Hydrol., 10, 282-290, doi:10.1016/0022-1694(70)90255-6, 1970.

Orlowsky, B., Hoekstra, A. Y., Gudmundsson, L., and Seneviratne, S. I.: Today's virtual water consumption and trade under future water scarcity, Environ. Res.Lett., 9, 074007, doi:10.1088/17489326/9/7/074007, 2014.

Oudin, L., Andréassian, V., Lerat, J., and Michel, C.: Has land cover a significant impact on mean annual streamflow? An international assessment using 1508 catchments, J. Hydrol., 357, 303316, doi:10.1016/j.jhydrol.2008.05.021, 2008.

Parajka, J., Viglione, A., Rogger, M., Salinas, J. L., Sivapalan, M., and Blöschl, G.: Comparative assessment of predictions in ungauged basins - Part 1: Runoff-hydrograph studies, Hydrol. Earth Syst. Sci., 17, 1783-1795, doi:10.5194/hess-17-17832013, 2013.

Prudhomme, C., Giuntoli, I., Robinson, E. L., Clark, D. B., Arnell, N. W., Dankers, R., Fekete, B. M., Franssen, W., Gerten, D., Gosling, S. N., Hagemann, S., Hannah, D. M., Kim, H., Masaki, Y., Satoh, Y., Stacke, T., Wada, Y., and Wisser, D.: Hydrological droughts in the 21st century, hotspots and uncertainties from a global multimodel ensemble experiment, P. Natl. Acad. Sci., 111, 3262-3267, doi:10.1073/pnas.1222473110, 2014.

Reager, J. and Famiglietti, J. S.: Characteristic mega-basin water storage behavior using GRACE, Water Resour. Res., 49, 3314 3329, doi:10.1002/wrcr.20264, 2013.

Reichstein, M., Bahn, M., Ciais, P., Frank, D., Mahecha, M. D., Seneviratne, S. I., Zscheischler, J., Beer, C., Buchmann, N., Frank, D. C., Papale, D., Rammig, A., Smith, P., Thonicke, K., van der Velde, M., Vicca, S., Walz, A., and Wattenbach, M.: Climate extremes and the carbon cycle, Nature, 500, 287-295, doi:10.1038/nature12350, 2013.

Robock, A., Schlosser, C. A., Vinnikov, K. Y., Speranskaya, N. A., Entin, J. K., and Qiu, S.: Evaluation of the AMIP soil moisture simulations, Global Planet. Change, 19, 181-208, doi:10.1016/S0921-8181(98)00047-2, 1998. 
Rodell, M. and Famiglietti, J. S.: Detectability of variations in continental water storage from satellite observations of the time dependent gravity field, Water Resour. Res., 35, 2705-2723, doi:10.1029/1999WR900141, 1999.

Rodell, M., Houser, P. R., Jambor, U., Gottschalck, J., Mitchell, K., Meng, C.-J., Arsenault, K., Cosgrove, B., Radakovich, J., Bosilovich, M., Entin, J. K., Walker, J. P., Lohmann, D., and Toll, D.: The Global Land Data Assimilation System, B. Am. Meteorol. Soc., 85, 381-394, doi:10.1175/BAMS-85-3-381, 2004.

Sauquet, E., Krasovskaia, I., and Leblois, E.: Mapping mean monthly runoff pattern using EOF analysis, Hydrol. Earth Syst. Sci., 4, 79-93, doi:10.5194/hess-4-79-2000, 2000.

Sawicz, K., Wagener, T., Sivapalan, M., Troch, P. A., and Carrillo, G.: Catchment classification: empirical analysis of hydrologic similarity based on catchment function in the eastern USA, Hydrol. Earth Syst. Sci., 15, 2895-2911, doi:10.5194/hess-15-28952011, 2011.

Schewe, J., Heinke, J., Gerten, D., Haddeland, I., Arnell, N. W., Clark, D. B., Dankers, R., Eisner, S., Fekete, B. M., ColónGonzález, F. J., Gosling, S. N., Kim, H., Liu, X., Masaki, Y., Portmann, F. T., Satoh, Y., Stacke, T., Tang, Q., Wada, Y., Wisser, D., Albrecht, T., Frieler, K., Piontek, F., Warszawski, L., and Kabat, P.: Multimodel assessment of water scarcity under climate change, P. Natl. Acad. Sci., 111, 3245-3250, doi:10.1073/pnas.1222460110, 2014.

Seneviratne, S. I., Corti, T., Davin, E. L., Hirschi, M., Jaeger, E. B., Lehner, I., Orlowsky, B., and Teuling, A. J.: Investigating soil moisture-climate interactions in a changing climate: A review, Earth-Sci. Rev., 99, 125-161, doi:10.1016/j.earscirev.2010.02.004, 2010.

Sheffield, J., Wood, E. F., and Roderick, M. L.: Little change in global drought over the past 60 years, Nature, 491, 435-438, doi:10.1038/nature11575, 2012.

Sivapalan, M., Takeuchi, K., Franks, S. W., Gupta, V. K., Karambiri, H., Lakshmi, V., Liang, X., Mc Donnell, J. J., Mendiondo, E. M., O’Connell, P. E., Oki, T., Pomeroy, J. W., Schertzer, D., Uhlenbrook, S., and Zehe, E.: IAHS Decade on Predictions in Ungauged Basins (PUB), 2003-2012: Shaping an exciting future for the hydrological sciences, Hydrol. Sci. J., 48, 857-880, doi:10.1623/hysj.48.6.857.51421, 2003.

Skøien, J. O. and Blöschl, G.: Spatiotemporal topological kriging of runoff time series, Water Resour. Res., 43, W09419, doi:10.1029/2006WR005760, 2007.

Skøien, J. O., Blöschl, G., and Western, A. W.: Characteristic space scales and timescales in hydrology, Water Resour. Res., 39, 1304, doi:10.1029/2002WR001736, 2003.

Skøien, J. O., Merz, R., and Blöschl, G.: Top-kriging - geostatistics on stream networks, Hydrol. Earth Syst. Sci., 10, 277-287, doi:10.5194/hess-10-277-2006, 2006.

Slack, J. R. and Landwehr, J. M.: Hydroclimatic Data Network (HCDN): A USGS Streamflow Data Set for the United States for the Study of Climate Variations, 1874-1988, USGS Open-File Report, 92, 129-193, available at: http://pubs.usgs.gov/of/1992/ ofr92-129/ (last access: 06 June 2015), 1992.

Stahl, K., Hisdal, H., Hannaford, J., Tallaksen, L. M., van Lanen, H. A. J., Sauquet, E., Demuth, S., Fendekova, M., and Jódar, J.: Streamflow trends in Europe: evidence from a dataset of nearnatural catchments, Hydrol. Earth Syst. Sci., 14, 2367-2382, doi:10.5194/hess-14-2367-2010, 2010.
Stahl, K., Tallaksen, L. M., Hannaford, J., and van Lanen, H. A. J.: Filling the white space on maps of European runoff trends: estimates from a multi-model ensemble, Hydrol. Earth Syst. Sci., 16, 2035-2047, doi:10.5194/hess-16-2035-2012, 2012.

Szolgayova, E., Laaha, G., Blöschl, G., and Bucher, C.: Factors influencing long range dependence in streamflow of European rivers, Hydrol. Process., 28, 1573-1586, doi:10.1002/hyp.9694, 2014.

Tallaksen, L. M. and Stahl, K.: Spatial and temporal patterns of large-scale droughts in Europe: Model dispersion and performance, Geophys. Res. Lett., 41, 429-434, doi:10.1002/2013GL058573, 2014.

Teuling, A. J., Uijlenhoet, R., van den Hurk, B., and Seneviratne, S. I.: Parameter Sensitivity in LSMs: An Analysis Using Stochastic Soil Moisture Models and ELDAS Soil Parameters, J. Hydrometeorol., 10, 751-765, doi:10.1175/2008JHM1033.1, 2009.

Thomas, A. C., Reager, J. T., Famiglietti, J. S., and Rodell, M.: A GRACE-based water storage deficit approach for hydrological drought characterization, Geophys. Res. Lett., 41, 1537-1545, doi:10.1002/2014GL059323, 2014.

Tootle, G. A. and Piechota, T. C.: Relationships between Pacific and Atlantic ocean sea surface temperatures and U.S. streamflow variability, Water Resour. Res., 42, W07411, doi:10.1029/2005WR004184, 2006.

van Werkhoven, K., Wagener, T., Reed, P., and Tang, Y.: Characterization of watershed model behavior across a hydroclimatic gradient, Water Resour. Res., 44, W01429, doi:10.1029/2007WR006271, 2008.

Viglione, A., Borga, M., Balabanis, P., and Blöschl, G.: Barriers to the exchange of hydrometeorological data in Europe: Results from a survey and implications for data policy, J. Hydrol., 394, 63-77, doi:10.1016/j.jhydrol.2010.03.023, 2010.

Vinnikov, K. Y., Robock, A., Speranskaya, N. A., and Schlosser, C. A.: Scales of temporal and spatial variability of midlatitude soil moisture, J. Geophys. Res., 101, 7163-7174, doi:10.1029/95JD02753, 1996.

Vörösmarty, C. J., McIntyre, P. B., Gessner, M. O., Dudgeon, D., Prusevich, A., Green, P., Glidden, S., Bunn, S. E., Sullivan, C. A., Liermann, C. R., and Davies, P. M.: Global threats to human water security and river biodiversity, Nature, 467, 555-561, doi:10.1038/nature09440, 2010.

Wagner, W., Blöschl, G., Pampaloni, P., Calvet, J.-C., Bizzarri, B., Wigneron, J.-P., and Kerr, Y.: Operational readiness of microwave remote sensing of soil moisture for hydrologic applications, Nord. Hydrol., 38, 1-20, doi:10.2166/nh.2007.029, 2007.

Weedon, G. P., Gomes, S., Viterbo, P., Shuttleworth, W. J., Blyth, E., Österle, H., Adam, J. C., Bellouin, N., Boucher, O., and Best, M.: Creation of the WATCH Forcing Data and Its Use to Assess Global and Regional Reference Crop Evaporation over Land during the Twentieth Century, J. Hydrometeorol., 12, 823-848, doi:10.1175/2011JHM1369.1, 2011.

Wilks, D. S.: Statistical Methods in the Atmospheric Sciences, vol. 100 of International Geophysics Series, Academic Press, 3 Edn., 2011.

Wong, T. H. F. and Laurenson, E. M.: Wave speed-discharge relations in natural channels, Water Resour. Res., 19, 701-706, doi:10.1029/WR019i003p00701, 1983.

Xia, Y., Mitchell, K., Ek, M., Cosgrove, B., Sheffield, J., Luo, L., Alonge, C., Wei, H., Meng, J., Livneh, B., Duan, Q., and 
Lohmann, D.: Continental-scale water and energy flux analysis and validation for North American Land Data Assimilation System project phase 2 (NLDAS-2): 2. Validation of modelsimulated streamflow, J. Geophys. Res.-Atmos., 117, D03110, doi:10.1029/2011JD016051, 2012.

Yaeger, M., Coopersmith, E., Ye, S., Cheng, L., Viglione, A., and Sivapalan, M.: Exploring the physical controls of regional patterns of flow duration curves - Part 4: A synthesis of empirical analysis, process modeling and catchment classification, Hydrol. Earth Syst. Sci., 16, 4483-4498, doi:10.5194/hess-16-44832012, 2012.
Ye, S., Yaeger, M., Coopersmith, E., Cheng, L., and Sivapalan, M.: Exploring the physical controls of regional patterns of flow duration curves - Part 2: Role of seasonality, the regime curve, and associated process controls, Hydrol. Earth Syst. Sci., 16, 4447 4465, doi:10.5194/hess-16-4447-2012, 2012.

Zaidman, M. D., Rees, H. G., and Young, A. R.: Spatio-temporal development of streamflow droughts in north-west Europe, Hydrol. Earth Syst. Sci., 6, 733-751, doi:10.5194/hess-6-733-2002, 2002. 